\title{
An Early Neogene Elasmobranch fauna from the southern Caribbean (Western Venezuela)
}

\author{
Jorge D. Carrillo-Briceño, Orangel A. Aguilera, Carlos De Gracia, \\ Gabriel Aguirre-Fernández, René Kindlimann, and Marcelo R. Sánchez-Villagra
}

\begin{abstract}
The Cantaure Formation (Burdigalian to ?early Langhian) is located in the Falcón Basin, North Western Venezuela, and includes one of the most diverse Neogene teleostean and benthonic invertebrate faunas in Tropical America. The paleoenvironmental preferences of the members of this fauna, as well as published paleogeographic reconstructions, suggest that the Cantaure Formation was deposited in a highly-productive shallow water environment, associated with coastal upwelling. We documented a paleodiversity of 39 shark and ray species, including 15 previously unreported taxa for Venezuela and six for Tropical America. We performed a bathymetric analysis of the fossil assemblage based on the distribution of closely-related extant chondrichthyan relatives of fossil taxa and discuss the ecological role and stratigraphic significance of the latter. Our results support the hypothesis that the Cantaure Formation was deposited in an insular inner-middle shelf environment. The elasmobranch fauna is characterized by a predominance of benthopelagic sharks with piscivorous feeding preferences (e.g., †Paratodus, Galeorhinus, Hemipristis, Rhizoprionodon, Carcharhinus, Isogomphodon, Negaprion, †Physogaleus and Sphyrna) followed by durophagous/cancritrophic feeders (e.g., Heterodontus, Nebrius, Mustelus, Rhynchobatus, Pristis, Dasyatis, cf. Pteroplatytrygon, cf. Taeniurops, Aetobatus, Aetomylaeus and Rhinoptera). Filter (e.g., Mobula and †Plinthicus), eurytrophic/sarcophagous (e.g., †Carcharocles and Galeocerdo) and teuthitrophic (e.g., Alopias) feeder species were also found. Teeth of Carcharocles megalodon found in Burdigalian sediments of the Cantaure Formation support the presence of this species already in the early Miocene. Some taxa (Nebrius, Carcharhinus cf. C. macloti and Rhynchobatus) are absent from the extant Caribbean and Western Atlantic fauna, but were present in the region before the closure of the Central American Seaway.
\end{abstract}

Jorge D. Carrillo-Briceño. Paleontological Institute and Museum, University of Zurich, Karl-Schmid-Strasse 4, Zürich, 8006, Switzerland. jorge.carrillo@pim.uzh.ch

Orangel A. Aguilera. Universidade Federal Fluminense, Instituto de Biologia, Departamento de Biologia Marinha, Programa de Pós-graduação em Biología Marinha. Campus do Valonguinho, Outeiro São João Batista, s/n. 24020-141, Niterói, RJ, Brasil. orangel.aguilera@gmail.com

Carlos De Gracia. Institute of Geology and Paleontology, Faculty of Science, Charles University in Prague,

Carrillo-Briceño, Jorge D., Aguilera, Orangel A., De Gracia, Carlos, Aguirre-Fernández, Gabriel, Kindlimann, René, and SánchezVillagra, Marcelo R. 2016. An Early Neogene Elasmobranch fauna from the southern Caribbean (Western Venezuela). Palaeontologia Electronica 19.2.27A: 1-32

palaeo-electronica.org/content/2016/1541-early-neogene-elasmobranchii 
Albertov 6, 12843 - Prague 2, Czech Republic. degraciac@gmail.com Gabriel Aguirre-Fernández. Paleontological Institute and Museum, University of Zurich, Karl-SchmidStrasse 4, Zürich, 8006, Switzerland. gabriel.aguirre@pim.uzh.ch

René Kindlimann. Paleontological Institute and Museum, University of Zurich, Karl-Schmid-Strasse 4, Zürich, 8006, Switzerland.mad_design@gmx.ch

Marcelo R. Sánchez-Villagra. Paleontological Institute and Museum, University of Zurich, Karl-SchmidStrasse 4, Zürich, 8006, Switzerland. m.sanchez@pim.uzh.ch

Keywords: Early Miocene; Burdigalian; Cantaure Formation; sharks; rays; Megalodon; paleoenvironment

\section{INTRODUCTION}

Sharks and rays are essential and diverse elements of tropical marine ecosystems (Cortés et al., 2008; Klimley, 2013), and their fossils are ubiquitous in many localities (e.g., Cappetta, 2012). In "Tropical America" - the geographic area of the Western Hemisphere located between the Tropic of Cancer and the Tropic of Capricorn, Neogene chondrichthyan assemblages are known from Barbados (Casier, 1958, 1966), Brazil (Santos and Travassos, 1960; Santos and Salgado, 1971; Reis, 2005; Costa et al., 2009), Cuba (Iturralde-Vinent et al., 1996; MacPhee et al., 2003), Southern Mexico (González-Rodríguez et al., 2013), Panama (Pimiento et al., 2013a), Peru (Alván et al., 2006), Trinidad (Leriche, 1938), The Grenadines (Portell et al., 2008) and Venezuela (Leriche, 1938; Sánchez-Villagra et al., 2000; Aguilera, 2010; Aguilera and Rodrigues de Aguilera, 2004; Aguilera and Lundberg, 2010). Despite all previous efforts, the chondrichthyan fossil record from the Caribbean is still fragmentary and poorly known, making it difficult to reconstruct paleofaunas that could help our understanding of the major ecological and biogeographical changes that happened in the area during the Neogene. Among those changes are those associated with the uplift of the Central American land bridge (Coates and Stallard, 2013; Montes et al., 2015), which interrupted the interoceanic corridor known as the Central American Seaway (CAS), and influenced the water circulation patterns of Pacific and the Caribbean (O'Dea et al., 2007, Leigh et al., 2014). The geographic position of Venezuelan deposits renders them as relevant for investigating the effects of those major paleogeographic rearrangements.

More than 20 years of paleontological expeditions in the Paraguaná Peninsula, North Western Venezuela, produced a collection of 1836 fossil elasmobranch specimens from the Cantaure Formation. This geological unit is thought to have been deposited under fully marine conditions (Díaz de Gamero, 1974; Rey, 1996), exhibiting a wellknown high diversity of invertebrates (Ingram, 1947; Jung, 1965; Gibson-Smith, 1974; GibsonSmith and Gibson-Smith, 1974; Aguilera et al., 2010; Landau et al., in press) and teleostean fishes (Nolf and Aguilera, 1998; Aguilera, 2010; Aguilera and Lundberg, 2010). We hereby present a new taxonomic study of the elasmobranch fauna from the Cantaure Formation and a discussion of the paleoenvironmental and feeding preferences of these elasmobranchs, based on comparisons with extant species.

\section{GEOLOGICAL AND STRATIGRAPHIC SETTING}

The Cantaure Formation (Jung, 1965) has been dated as early Miocene, based on biozones of planktonic foraminifera (N7-8) and calcareous nannofossils (NN4-5) (Díaz de Gamero, 1974; Rey, 1996). According to Gradstein et al. (2012), biozones N7 and N8 correspond to the Lower to Middle Miocene transition (upper Burdigalian to lower Langhian). Griffiths et al. (2013) assigned a Burdigalian age $(16.5 \pm 0.4 \mathrm{Ma}$.) to a horizon of the Cantaure Formation using $\mathrm{Sr}$ isotopes from corals (Figure 1.2). Landau et al. (in press) suggested that the gastropod assemblage from The Cantaure Formation is typical for early-middle Miocene deposits. The stratotype of the Cantaure Formation is located approximately $10 \mathrm{~km}$ west of Pueblo Nuevo on the Paraguaná Peninsula, Falcón State, Venezuela. Outcrops are found south of Casa Cantaure (Figure 1.1) and are composed of fossiliferous silty shales interbedded with thin algal limestones and shell beds (Hunter and Bartok, 1974). Jung (1965) estimated a thickness of $75 \mathrm{~m}$ for the composit section of the Cantaure Formation. Hunter and Bartok (1974) divided the Cantaure Formation into three sections: 1) fossiliferous basal breccia unconformably overlaying the granite basement, 2) lower section comprised mainly of 

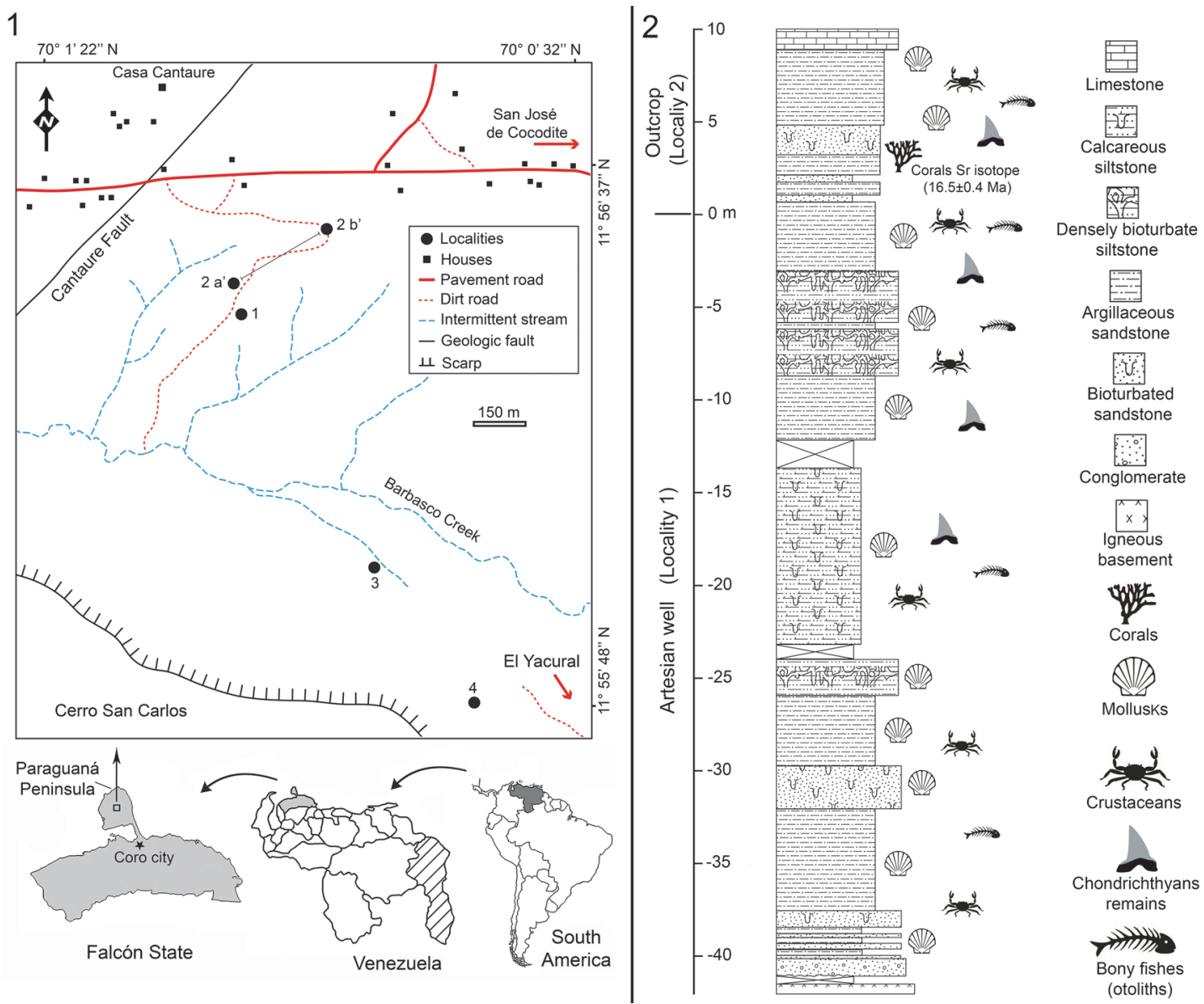

FIGURE 1. Location and stratigraphy of the Cantaure Formation. 1. Fossiliferous localities. 2. Stratigraphic section of locality 1 (artesian well) and locality 2 (outcrop). Stratigraphic column modified after Aguilera (2010) and Aguilera et al. (2013).

shales and some sandy horizons [including the mollusk rich horizons illustrated by Jung (1965)], and 3) upper section represented by silty shales interbedded with thin algal limestones and shell beds. However, Hunter and Bartok (1974) did not provide a stratigraphic column, while they mentioned that the landscape of the area prevents a detailed measurement of the complete section. In contrast, Rey (1996) constructed a stratigraphic column of the suggested basal and middle sections, and also assumed that the mollusks described by Jung (1965), Gibson-Smith (1974) and Gibson-Smith and Gibson-Smith (1974), were derived from the upper section.

The top of the Cantaure Formation is conformably overlain by limestone layers that have been interpreted by Jung (1965) and Hunter and Bartok (1974) as post-Cantaure and pre-Pliocene sedimentation. Rey (1996) suggested that the upper contact of the Cantaure Formation represents an unconformity with the Amuay Member (early Pliocene) of the Paraguaná Formation. Our field observations (OAA, JDCB, pers. obs.) indicate possible lateral variations in a short distance, with fossiliferous outcrops (e.g., thick layers of barnacles) that are not exposed in the previously known and described fossiliferous localities (e.g., Jung, 1965; Hunter and Bartok, 1974; Rey, 1996, among others). All the above clearly indicates that the Cantaure Formation is a more complex sequence than previously thought, in need of a new, detailed stratigraphic redescription.

\section{MATERIAL AND METHODS}

The fossil elasmobranch fauna described here (Table 1; Appendix 1) consists of 1836 specimens from four localities in the Cantaure Formation (Figure 1.1), which have been collected by the authors and other collaborators during several expeditions since 1992 . Locality $1\left(11^{\circ} 56^{\prime} 20^{\prime \prime} \mathrm{N}\right.$, $70^{\circ} 1$ ' 2" W) corresponds to an artesian well $\sim 44 \mathrm{~m}$ deep (Figure 1.2) and locality 2 (a': $11^{\circ} 56^{\prime} 23^{\prime \prime} \mathrm{N}$, 
TABLE 1. Elasmobranchii paleodiversity of the Cantaure Formation.

\begin{tabular}{|c|c|c|c|c|}
\hline Superorder & Order & Family & Genus & Taxon \\
\hline \multirow[t]{18}{*}{ Galeomorphii } & Heterodontiformes & Heterodontidae & Heterodontus & Heterodontus sp. \\
\hline & Orectolobiformes & Ginglymostomatidae & Nebrius & Nebrius sp. \\
\hline & Lamniformes & †Otodontidae & †Paratodus & $†$ Paratodus benedenii (Le Hon, 1871) \\
\hline & & & †Carcharocles & $\begin{array}{l}\text { †Carcharocles megalodon (Agassiz, } \\
\text { 1843) }\end{array}$ \\
\hline & & Alopiidae & Alopias & $\begin{array}{l}\text { Alopias cf. A. vulpinus (Bonnaterre, } \\
\text { 1788) }\end{array}$ \\
\hline & Carcharhiniformes & Triakidae & Galeorhinus & $\begin{array}{l}\text { Galeorhinus cf. G. galeus (Linnaeus, } \\
\text { 1758) }\end{array}$ \\
\hline & & & Mustelus & Mustelus sp. \\
\hline & & Hemigaleidae & Hemipristis & †Hemipristis serra (Agassiz, 1835) \\
\hline & & Carcharhinidae & Galeocerdo & †Galeocerdo aduncus Agassiz, 1843 \\
\hline & & & & $\begin{array}{l}\text { †Galeocerdo mayumbensis Dartevelle } \\
\text { and Casier, } 1943\end{array}$ \\
\hline & & & Rhizoprionodon & Rhizoprionodon sp. \\
\hline & & & Carcharhinus & $\begin{array}{l}\text { †Carcharhinus ackermannii Santos \& } \\
\text { Travassos, } 1960\end{array}$ \\
\hline & & & & $\begin{array}{l}\text { Carcharhinus brachyurus(Günther, } \\
1870 \text { ) }\end{array}$ \\
\hline & & & & $\begin{array}{l}\text { Carcharhinus falciformis(Müller and } \\
\text { Henle, 1839) }\end{array}$ \\
\hline & & & & $\begin{array}{l}\text { Carcharhinus cf. C. galapagensis } \\
\text { (Snodgrass and Heller, 1905) }\end{array}$ \\
\hline & & & & $\begin{array}{l}\text { †Carcharhinus gibbesii (Woodward, } \\
\text { 1889) }\end{array}$ \\
\hline & & & & $\begin{array}{l}\text { Carcharhinus cf. C. limbatus (Müller and } \\
\text { Henle, 1839) }\end{array}$ \\
\hline & & & & $\begin{array}{l}\text { Carcharhinus cf. C. macloti (Müller and } \\
\text { Henle, 1839) }\end{array}$ \\
\hline
\end{tabular}

$70^{\circ} 1^{\prime} 3^{\prime \prime} \mathrm{W}$ and b': $11^{\circ} 56^{\prime} 2^{\prime \prime} \mathrm{N}, 70^{\circ} 0^{\prime} 55^{\prime \prime} \mathrm{W}$ ) is an outcrop (overlying the section of locality 1 ) with a $\sim 300 \mathrm{~m}$ long collecting surface (Figures 1.1-1.2). The corals used by Griffiths et al. (2013) for Sr isotope analysis were collected at locality 2 (Figure 1.1-1.2). This suggests that localities 1 and at least the lower section of locality 2 are of Burdigalian age (Figure 1.2). Localities $3\left(11^{\circ} 55^{\prime} 59^{\prime \prime} \mathrm{N}, 70^{\circ} 1^{\prime}\right.$ 1 " W) and $4\left(11^{\circ} 55^{\prime} 48^{\prime \prime} \mathrm{N}, 70^{\circ} 00^{\prime} 40^{\prime \prime} \mathrm{W}\right)$ correspond to surface collecting areas along the south of Barbasco Creek, on the north escarpment of the Cerro San Carlos (Figure 1.1). Without a detailed stratigraphical knowledge of the outcrops south of Barbasco Creek, it is not possible to establish if localities 3 and 4 are different vertical strata (facies) along the Cantaure section or horizontal variations of localities 1 and 2 . Field observations (OAA, JDCB and GAF pers. obs.) suggest that localities 3 and 4 are stratigraphically older than the limestones layers attributed to post-Cantaure sedimentation (Jung, 1965; Hunter and Bartok, 1974).

Large specimens were surface-collected directly from the outcrop, while microsamples were collected after screen-washing approximately 1000 and $380 \mathrm{~kg}$ of sediments (mesh sizes: 0.5 and 2 $\mathrm{mm}$ ) from locality 1 and 2, respectively. Approximately $50 \mathrm{~kg}$ of sediment was processed from locality 3 , but it did not contain otoliths or elasmobranch micro-teeth. Specimens from locality 4 were only surface collected. The Cantaure specimens (Appendix 2) are housed in the paleontological collections of the Alcaldía Bolivariana de Urumaco (AMU-CURS), Centro de Investigaciones Antropológicas, Arqueológicas y Paleontológicas of the Universidad Experimental Francisco de Miranda (CIAAP, UNEFM-PF), and the Museo de Ciencias de Caracas (MCNC), all in Venezuela. 
TABLE 1 (continued).

\begin{tabular}{|c|c|c|c|c|}
\hline Superorder & Order & Family & Genus & Taxon \\
\hline & & & & Carcharhinus perezi (Poey, 1876) \\
\hline & & & & Carcharhinus sp. 1 \\
\hline & & & & Carcharhinus spp. \\
\hline & & & Isogomphodon & †/sogomphodon acuarius (Probst, 1879) \\
\hline & & & Negaprion & †Negaprion eurybathrodon (Blake, 1862) \\
\hline & & & †Physogaleus & †Physogaleus contortus (Gibbes, 1849) \\
\hline & & & Gen. indet. & sp. indet. \\
\hline & & Sphyrnidae & Sphyrna & †Sphyrna arambourgi Cappetta, 1970 \\
\hline & & & & Sphyrna cf. †S. laevissima (Cope, 1867) \\
\hline \multirow[t]{15}{*}{ Batomorphii } & Rajiformes & Rhynchobatidae & Rhynchobatus & Rynchobatus sp. \\
\hline & & Pristidae & Pristis & Pristis sp. \\
\hline & Myliobatiformes & Dasyatidae & Dasyatis & Dasyatis sp. \\
\hline & & & cf. Pteroplatytrygon & cf. Pteroplatytrygon sp. \\
\hline & & & cf. Taeniurops & cf. Taeniurops sp. \\
\hline & & & & Dasyatidae Indet. \\
\hline & & Myliobatidae & Aetobatus & Aetobatus sp. \\
\hline & & & Aetomylaeus & Aetomylaeus sp. \\
\hline & & Rhinopteridae & Rhinoptera & Rhinoptera sp. \\
\hline & & Mobulidae & Mobula & †Mobula fragilis (Cappetta, 1970) \\
\hline & & & & $\begin{array}{l}\text { Mobula cf. } † \text { M. loupianensis (Cappetta, } \\
\text { 1970) }\end{array}$ \\
\hline & & & & Mobula sp. \\
\hline & & & †Plinthicus & †Plinthicus stenodon Cope, 1869 \\
\hline & & & & Myliobatiformes indet. \\
\hline & & & & Chondrichthyes indet. \\
\hline
\end{tabular}

The taxonomy follows Cappetta (2012) and Compagno (2005), with the exception of the extinct genus Carcharocles Jordan and Hannibal, 1923, for which we follow the nomenclature of Pimiento et al. (2010). Taxonomic identification was based on an extensive literature review, and also comparative analyses between fossil and recent specimens from the following collections: Mapuka Museum of Universidad del Norte (MUN-STRI), Barranquilla, Colombia; Museu Paraense Emilio Goeldi (MPEG-V), Belem, Brazil; Natural History Museum of Basel (NMB), Switzerland; Paleontological collection of the Institut des Sciences de I' Evolution, University of Montpellier (UM), France; Palaeontological Institute and Museum at the University of Zurich (PIMUZ), Switzerland and René Kindlimann private collection, Uster, Switzerland.

We analyzed the abundance using percentages of specimens by order, families and species using the 39 securely recognized taxa that are represented by 1711 specimens (out of the 1836 collected in total) (Appendix 1). For conducting the paleoecological interpretation, we compiled information on habitat preference (benthic, benthopelagic, pelagic, neritic and bathyal) and feeding ecology (dietary composition and behavior) of extant taxa recorded in the Cantaure Formation (Appendix 3), following Compagno (1984a, 1984b); Cortés (1999); Compagno et al. (2005); Musick et al. (2004); Kiraly et al. (2003); Voigt and Weber (2011); Cortés et al. (2008); Ebert and Stehmann (2013); and the FishBase website (Froese and Pauly, 2015). The paleobathymetric analysis was performed following the methodology of Nolf and Brzobohatý (1994), adapted to fossil sharks (Carrillo-Briceño et al., 2015a, 2016). For this analysis we included only species/genera with closely related extant taxa. Extinct species and taxa with- 
out clear identification to genus were removed from the analysis. A total of 34 (out of 39) taxa, for which ecological information is available, were analyzed.

Taking into consideration the limitations associated with paleoecological interpretations of fossil assemblages, we tried to approach the ecological role that members of the Cantaure elasmobranch fauna played in this ancient marine environment. We use the categorization of elasmobranch feeding preferences suggested by Cortés (1999) and Cortés et al. (2008). Living sharks and rays as a whole exhibit a wide range of diets, but each species has specific preferences. The latter are used to infer the diet of taxa we documented from the Cantaure assemblage (Appendix 3).

\section{RESULTS}

\section{Taxonomical Composition}

The taxonomical composition of the four study localities includes at least 39 species of galeomorphs and batoids (Table 1; Appendix 1, 4). Galeomorphs are represented by 26 species, 15 genera and eight families of Heterodontiformes, Orectolobiformes, Lamniformes and Carcharhiniformes (Table 1; Figure 2). Batoids include 13 species attributed to 10 genera and six families of Rajiformes and Myliobatiformes (Table 1; Figure 2). Pictures of the chondrichthyan teeth, vertebrae and caudal and rostral denticles in Figures 3-12, were illustrated following the taxonomic classification shown in Table 1.

Heterodontiformes Berg, 1937. The record of this group (Heterodontidae Gray, 1851) consists of a single and undetermined specimen of Heterodontus Blainville, 1816. The tooth was collected from locality 2 (Appendix 1, 4), and was previously reported by Aguilera and Lundberg (2010) and Aguilera (2010). The specimen is missing from the UNEFM collection and it is not illustrated here.

Orectolobiformes Applegate, 1972. The orectolobiform specimens are characterized by a long apron and a short main cusp flanked by more than seven pairs of lateral cusplets (Figure 3.1-3.9). This condition is diagnostic for Nebrius Rüppell, 1837, a genus recorded from North America going back to the Eocene (e.g., Kent, 1994; Müller, 1999). The specimens from the Cantaure assemblage (Figure 3.1-3.9; Appendix 1, 4) were previously assigned to Ginglymostoma delfortriei (Daimeries, 1889) (Aguilera and Rodrigues de Aguilera, 2004; Aguilera, 2010; Aguilera and Lundberg, 2010). Fossils of Nebrius in the Americas have not been thoroughly studied, and there is no clear consensus about their taxonomy at the species level or stratigraphic range (e.g., Kent, 1994; Cicimurri and Knight, 2009). Therefore we refrain from assigning species to our specimens. Cicimurri and Knight (2009) suggested that some fossil teeth of Nebrius (from North America) have been misidentified as Ginglymostoma Müller and Henle, 1837. The specimens referred to $G$. delfortriei from Panama (Pimiento et al., 2013b) and Ginglymostoma sp. from Brazil (Costa et al., 2009) resemble our Nebrius teeth from the Cantaure Formation.

Lamniformes Berg, 1937. These sharks are represented by one species of Alopiidae Bonaparte, 1838 and two genera and two species of †Otodontidae Glikman 1964 (Figure 2). Alopias cf. A. vulpinus (Bonnaterre, 1788) is represented by three specimens (Figure 3.22-3.26; Appendix 1,3) while the otodontid †Paratodus benedenii (Le Hon, 1871 ) is the least abundant lamniform (Figure 3.10-3.11; Appendix 1, 4). The most abundant lamniform is the otodontid †Carcharocles megalodon (Agassiz, 1843), with more than 100 specimens (Figure 3.12-3.21) from all studied localities (Appendix 1, 4). Many C. megalodon teeth are broken; however, most of them, especially large specimens, preserve the wide triangular shape (crown without lateral cusplets), a v-shaped 'neck', a fine serrations, and the large size that characterize this species (Purdy et al., 2001; Cappetta, 2012; Pimiento et al., 2010, 2013b). Small teeth having a pair of short lateral cusplets may belong to juvenile and/or subadult individuals of $C$. megalodon (Figure 3.12-3.16), a feature not present in adult teeth (Figure 3.17-3.21). Morphologically, the younger species Carcharocles chubutensis (Ameghino, 1901), differs from C. megalodon by the presence of lateral cusplets not separated from the crown on the teeth of juveniles, subadults and adults (Cappetta, 2012; Pimiento et al., 2013a). In more derived populations as $C$. megalodon, lateral cusplets disappear, except sometimes on very lateral files or in juvenile individuals (Cappetta, 2012). This absence of lateral cusplets in C. megalodon adult teeth has been interpreted as the result of heterochronic processes in the Carcharocles clade through geologic time (Pimiento et al., 2010, 2013a, 2013b; Pimiento and Balk, 2015). The absence of lateral cusplets in all well-preserved teeth interpreted as adults (including also some teeth that may belong to juvenile/subadults specimens) allows us to assign our specimens to $C$. megalodon. In addition, adult teeth of C. megalodon referred here, are very similar to those of the 


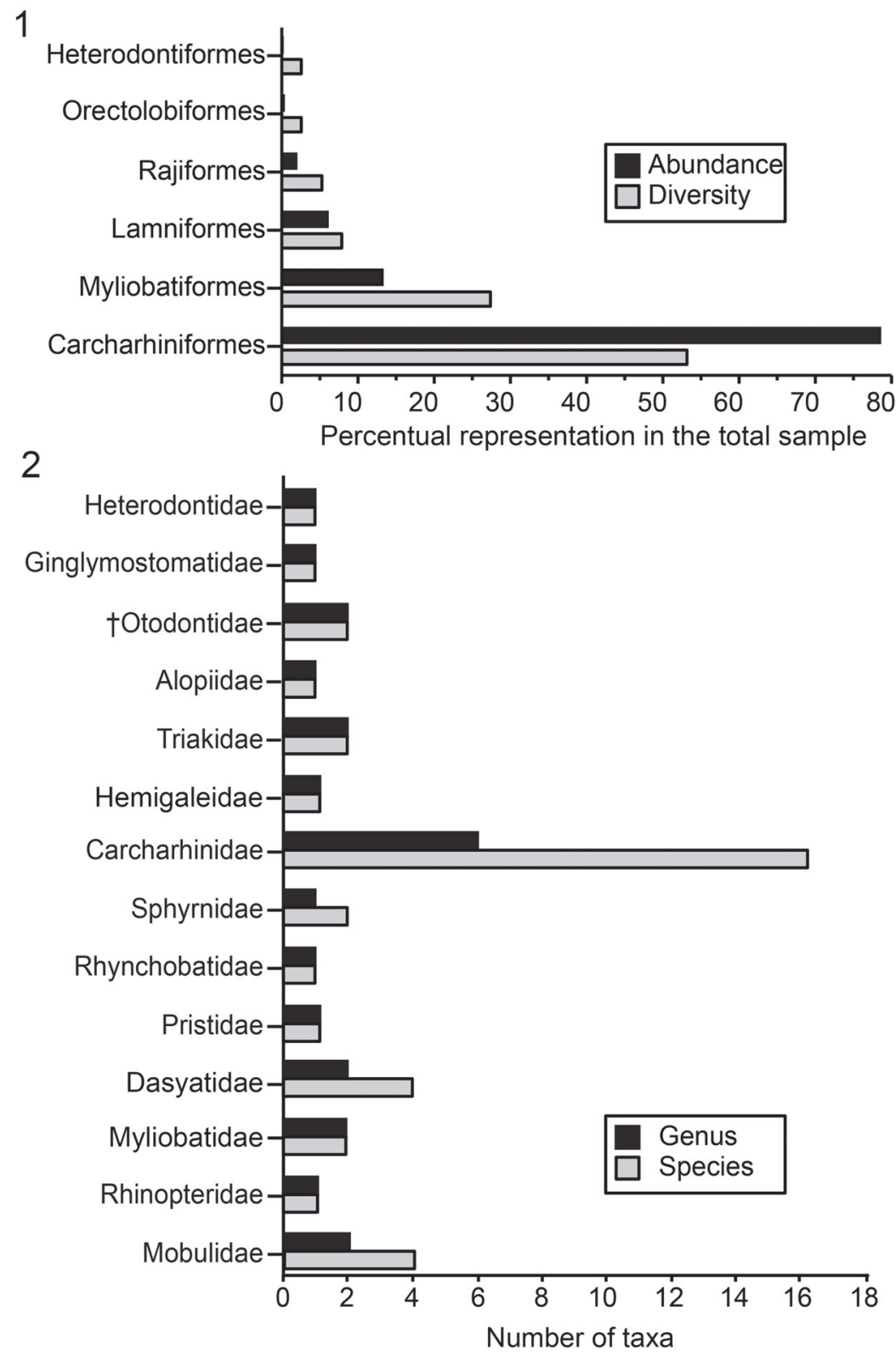

FIGURE 2. Elasmobranch paleodiversity of the Cantaure Formation. 1. Orders and 2. Families and genera.

same species, found in the late Burdigalian section ( 16.2 Ma.) of the Castilletes Formation at North East Colombia (under study by JDCB).

Carcharhiniformes Compagno, 1973. This order is represented by four families, 10 genera and 21 species, thus being the most abundant and diverse one of the Cantaure assemblage (Figures 2, 4-8; Table 1; Appendix 1, 4). Triakidae Gray, 1851 [two genera and two species: Galeorhinus cf. G. galeus (Linnaeus, 1758) (Figure 4.1-4.2), and Mustelus Linck, 1790 (Mustelus sp.) (Figure 4.3-4.7)], Hemigaleidae Hasse, 1879 [†Hemipristis serra (Agassiz, 1835) (Figure 4.8-4.13)], and Sphyrnidae Gill,
1872 [†Sphyrna arambourgi Cappetta, 1970 (Figure 7.21-7.25), and Sphyrna cf. †S. laevissima (Cope, 1867) (Figure 8.1-8.5)], are the less diverse families of this order in the Cantaure assemblage (Figure 2; Appendix 1, 4). Nevertheless, Hemipristis serra with 425 specimens (Appendix 1,4), is the second most abundant species of the assemblage, representing $23 \%$ of the total specimens collected. The specimen referred by Aguilera and Rodrigues de Aguilera (2004) to Paragaleus sp. corresponds to a juvenile posterior ?lower tooth of $H$. serra (Figure 4.8). 


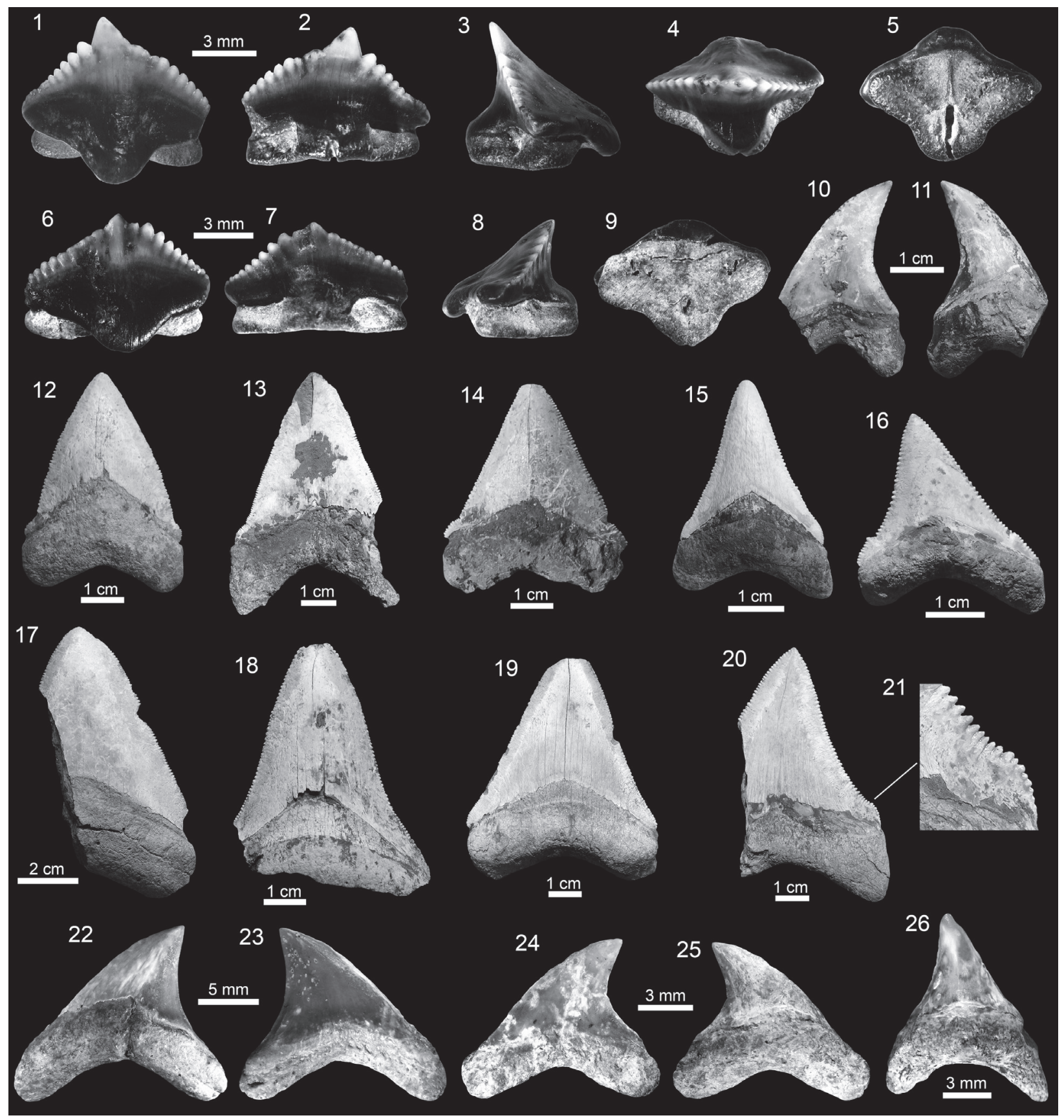

FIGURE 3. Orectolobiformes and Lamniformes of the Cantaure Formation. 1-9. Nebrius sp. (AMU-CURS-986); $10-11$. †Paratodus benedenii (AMU-CURS-645). 12-21. †Carcharocles megalodon (12: AMU-CURS-997; 13: AMU-CURS512; 14: UNEFM-PF-349; 15: AMU-CURS-996; 16: AMU-CURS-518; 17-18: UNEFM-PF-s/n; 19 : AMU-CURS-512 and 20-21: AMU-CURS-515). 22-26. Alopias cf. A. vulpinus (22-23: AMU-CURS-985; 24-25: AMU-CURS-983 and 26: AMU-CURS-984). Jaw position: upper (10-11? 12, 14? 17, 22-25), lower $(13,15,18)$ and indet. (1-9, 16, 19-21, 26). View: labial $(1,6,10,13,20-21,23,24)$, lingual $(2,7,11-12,14-19,22,25-26)$, profile $(3,8)$, occlusal (4) and basal $(5,9)$. 


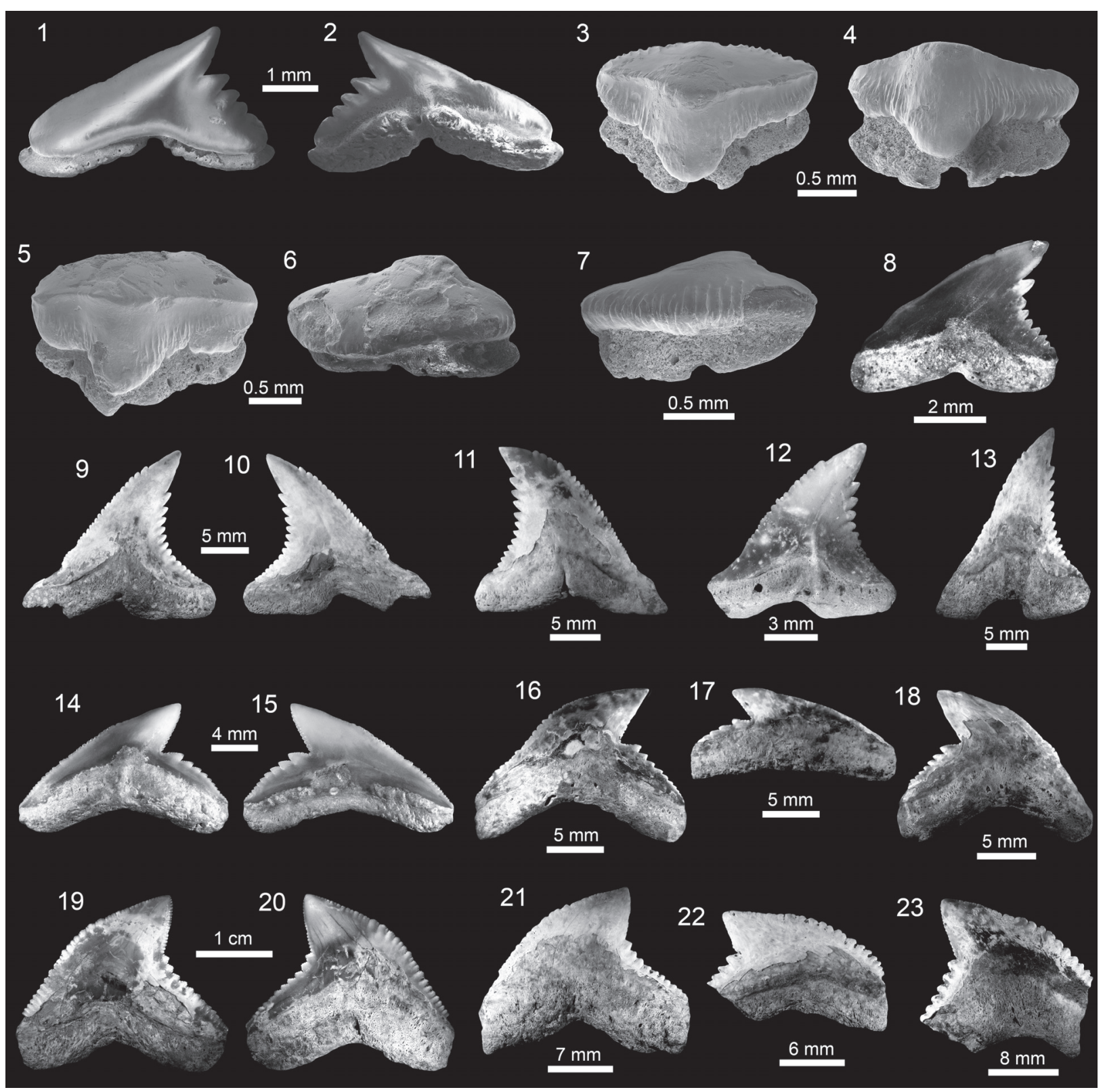

FIGURE 4. Carcharhiniformes of the Cantaure Formation. 1-2. Galeorhinus cf. G. galeus (AMU-CURS-974). 3-7. Mustelus sp. (AMU-CURS-975). 8-13. †Hemipristis serra (8: AMU-CURS-731 and 9-13: AMU-CURS-644). 14-18. †Galeocerdo aduncus (14-15: AMU-CURS-730 and 16-18: AMU-CURS-647). 19-23. †Galeocerdo mayumbensis (19-20: AMU-CURS-995 and 21-23: AMU-CURS-646). Jaw position: upper (9-12), lower (8? 13) and indet. (1-7, 1423). View: labial $(1,6,7,10,15,19,21-22)$, lingual $(2,4,8-9,11-14,16-18,20,23)$ and occlusal-lingual $(3,5)$.

The Carcharhinidae Jordan and Evermann, 1896, with six genera and 16 species, is the most diverse and abundant family of the assemblage (Figure 2; Table 1; Appendix 1, 4). The genera Rhizoprionodon Whitley, 1929 [Rhizoprionodon sp. (Figure 5.15.5)], Isogomphodon Gill, 1862 [†/sogomphodon acuarius (Probst, 1879) (Figure 7.1-7.5)], Negaprion Whitley, 1940 [†Negaprion eurybathrodon (Blake, 1862) (Figure 7.6-7.10)], and †Physoga- leus Cappetta, 1980 [†Physogaleus contortus (Gibbes, 1849) (Figure 7.11-7.15)], are represented by one species each. Galeocerdo Müller and Henle, 1837 is represented by two species [ $†$ Galeocerdo aduncus Agassiz, 1843 (Figure 4.144.18), and †Galeocerdo mayumbensis Dartevelle and Casier, 1943 (Figure 4.19-4.23)]. Negaprion eurybathrodon with 586 specimens (Appendix 1, 4) is the most abundant species of the assemblage, 


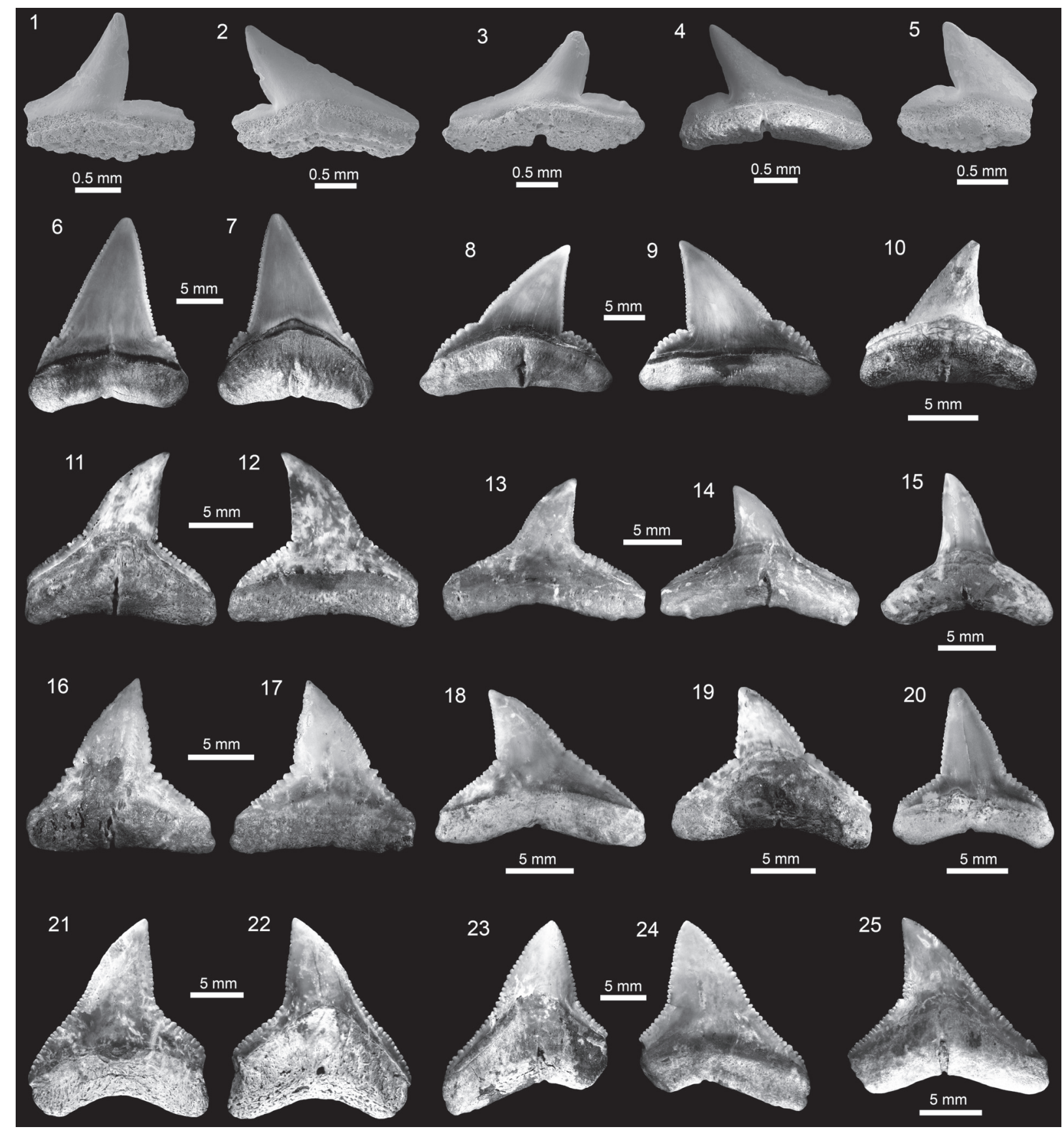

FIGURE 5. Carcharhiniformes of the Cantaure Formation. 1-5. Rhizoprionodon sp. (1-3, 5: AMU-CURS-975 and 4: AMU-CURS-960). 6-10. †Carcharhinus ackermannii (6-7: AMU-CURS-713 and 8-10: AMU-CURS-714). 11-15. Carcharhinus brachyurus (AMU-CURS-990). 16-20. Carcharhinus falciformis (AMU-CURS-991). 21-25. Carcharhinus cf. C. galapagensis (AMU-CURS-973). Jaw position: upper (2, 4-14, 16-25) and lower (1, 3. 15). View: labial (6, 9, 12$13,17-18,20-21,24)$ and lingual (1-5, 7-8, 10-11, 14-16, 19, 22-23, 25).

representing $32 \%$ of the total specimens collected. Specimens referred to Mustelus sp. (Triakidae) and Rhizoprionodon sp. (Carcharhinidae), are few and fragmentary, lacking diagnostic characters for accurate species assignment.

The genus Carcharhinus Blainville, 1816, with nine species, represents the most diverse genus from the Cantaure assemblage (Figures 2, 5.65.25, 6.1-6.24; Table 1; Appendix 1, 4). With the exception of the extinct †Carcharhinus ackermannii Santos and Travassos, 1960 (Figure 5.6-5.10) and †Carcharhinus gibbesii (Woodward, 1889) (Figure 6.1-6.4), the species Carcharhinus brachyurus (Günther, 1870) (Figure 5.11-5.15), 


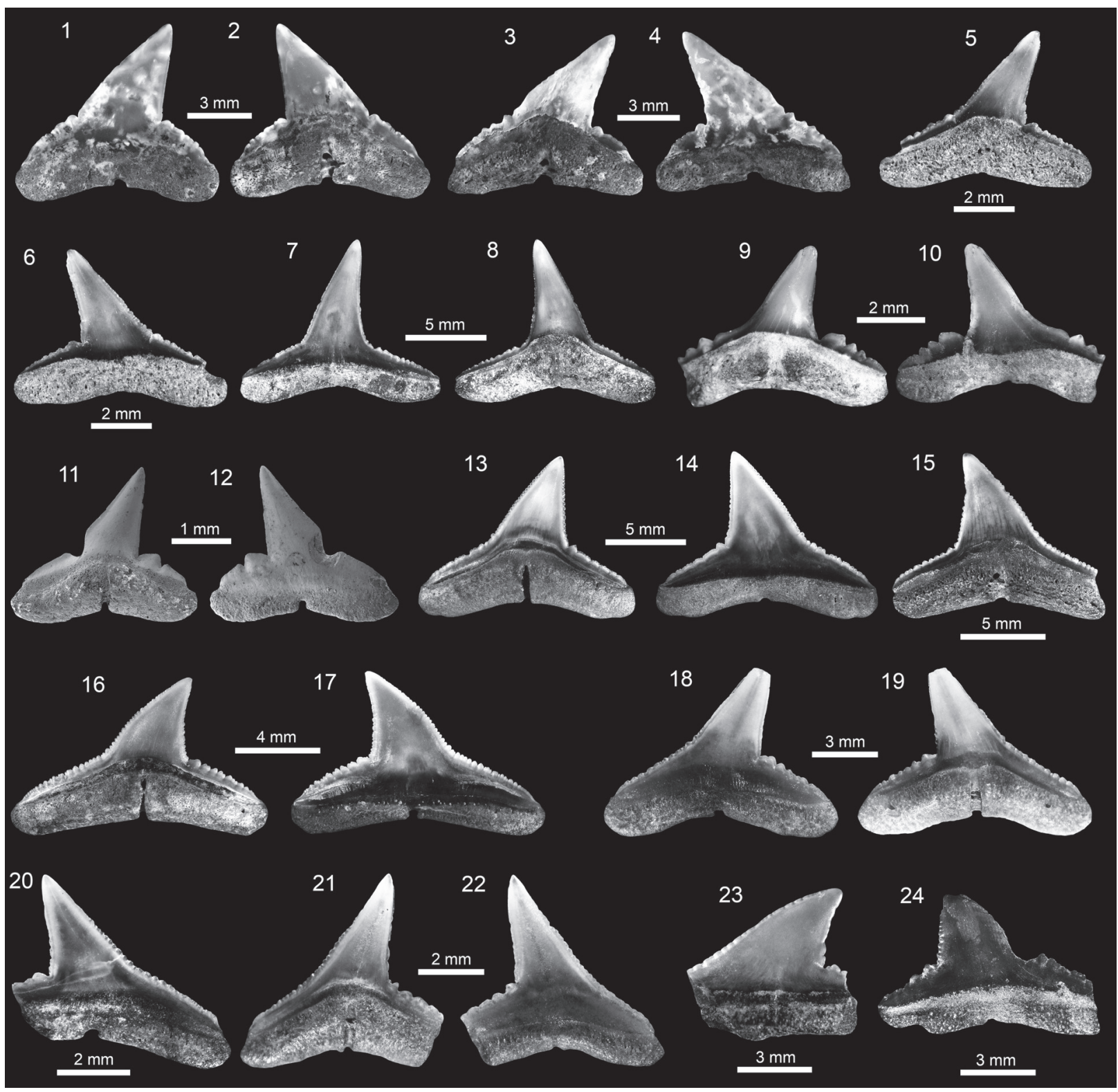

FIGURE 6. Carcharhiniformes of the Cantaure Formation. 1-4. †Carcharhinus gibbesii (AMU-CURS-958). 5-8. Carcharhinus cf. C. limbatus (AMU-CURS-944). 9-12. Carcharhinus cf. C. macloti (AMU-CURS-957). 13-17. Carcharhinus perezi (AMU-CURS-956). 18-22. Carcharhinus sp.1 (AMU-CURS-943). 23-24. Carcharhinus spp. (23: AMUCURS-941 and 24: AMU-CURS-940). Jaw position: upper (1-24). View: labial (1, 4, 6-7, 10, 12, 14, 17-18, 20, 22-24) and lingual $(2-3,5,8-9,11,13,15-16,19,21)$.

Carcharhinus falciformis (Müller and Henle, 1839) (Figure 5.16-5.20), Carcharhinus cf. C. galapagensis (Snodgrass and Heller, 1905) (Figure 5.215.25), Carcharhinus cf. C. limbatus (Müller and Henle, 1839) (Figure 6.5-6.8) and Carcharhinus perezi (Poey, 1876) (Figure 6.13-6.17), have living counterparts and most of them inhabit the Atlantic and Pacific coast of America (Compagno et al., 2005). Carcharhinus macloti (Müller and Henle, 1839) (Figure 6.9-6.12) is today an exclusive inhabitant of the Indo-west Pacific Ocean (Compagno et al., 2005). The specimens referred to Carcharhinus sp.1 (Figure 6.18-6.22), have a dental morphology different, especially in the form of the crown, which differentiate these teeth from the rest of the Carcharhinus species found in the Cantaure assemblage. Due to the scarcity of specimens (Appendix 1) and the lack of preserved diagnostic characters in Carcharhinus teeth we have used for comparison (fossil and recent speci- 


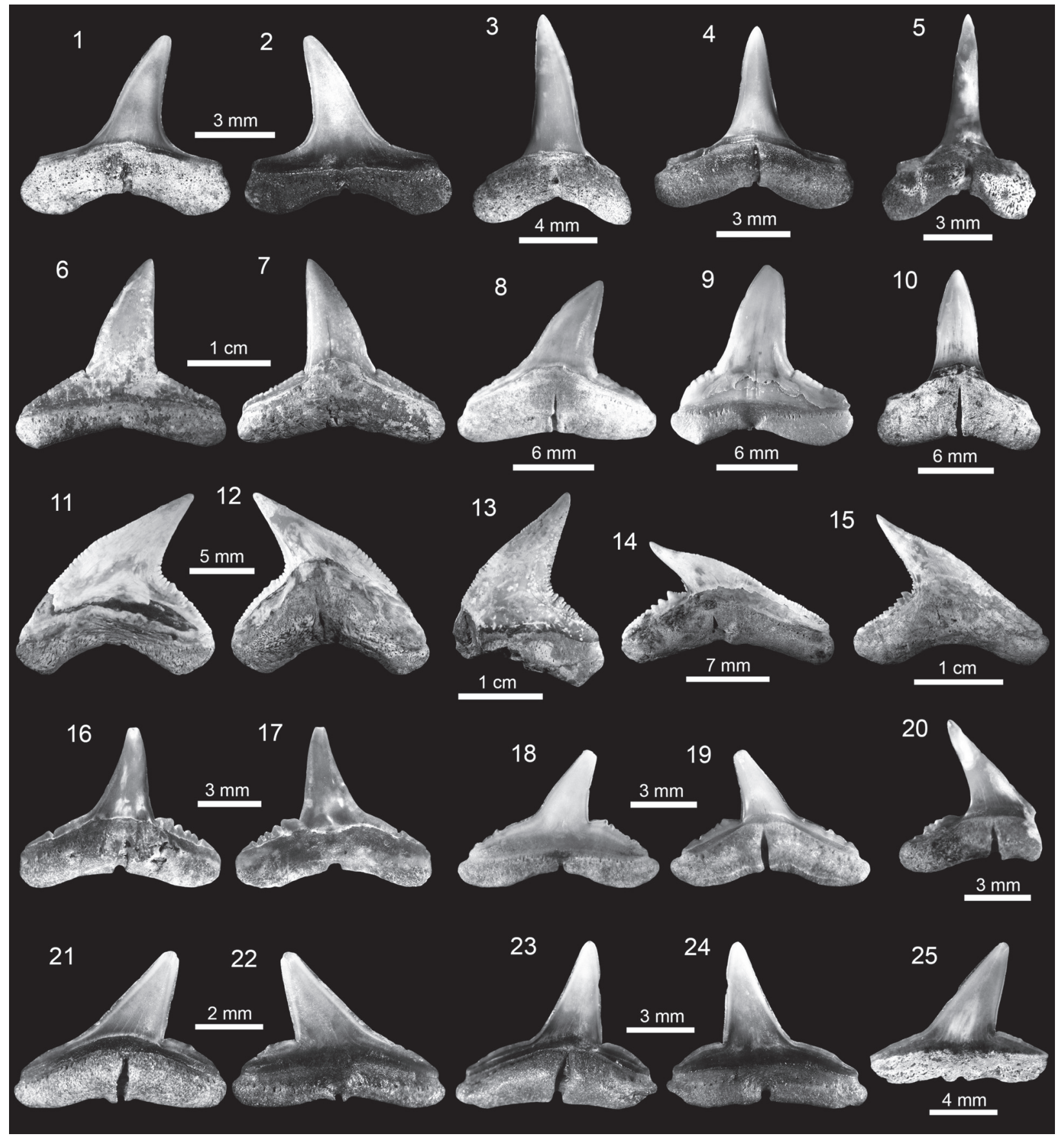

FIGURE 7. Carcharhiniformes of the Cantaure Formation. 1-5. †/sogomphodon acuarius (1-2: AMU-CURS-950 and 35: AMU-CURS-951). 6-10. †Negaprion eurybathrodon (6-9: AMU-CURS-989 and 10: AMU-CURS-987). 11-15. †Physogaleus contortus (11-12: AMU-CURS-719 and 13-15: AMU-CURS-648). 16-20. Carcharhinidae indet. (AMUCURS-939). 21-25. †Sphyrna arambourgi (21-24: AMU-CURS-961 and 25: AMU-CURS-962). Jaw position: upper (13, 6-9, 16-19? 21-22, 25), lower (4-5, 10, 20? 23-24) and indet. (11-15). View: labial (2, 6, 9, 11, 13, 17-18, 22, 24-25) and lingual $(1,3-5,7-8,10,12,14-16,19-21,23)$.

mens), we prefer to keep these specimens to a generic level. We have referred all specimens that are broken and eroded, without any diagnostic features for specific identification (Figure 6.23-6.24), to Carcharhinus spp. Some of the specimens clas- sified as Carcharhinidae indet. (Figure 7.16-7.20; Table 1; Appendix 1,4), exhibit a very prominent lingual protuberance with a sigmoid cusp, which could be the basis of a more detailed taxonomical identification in future studies. 


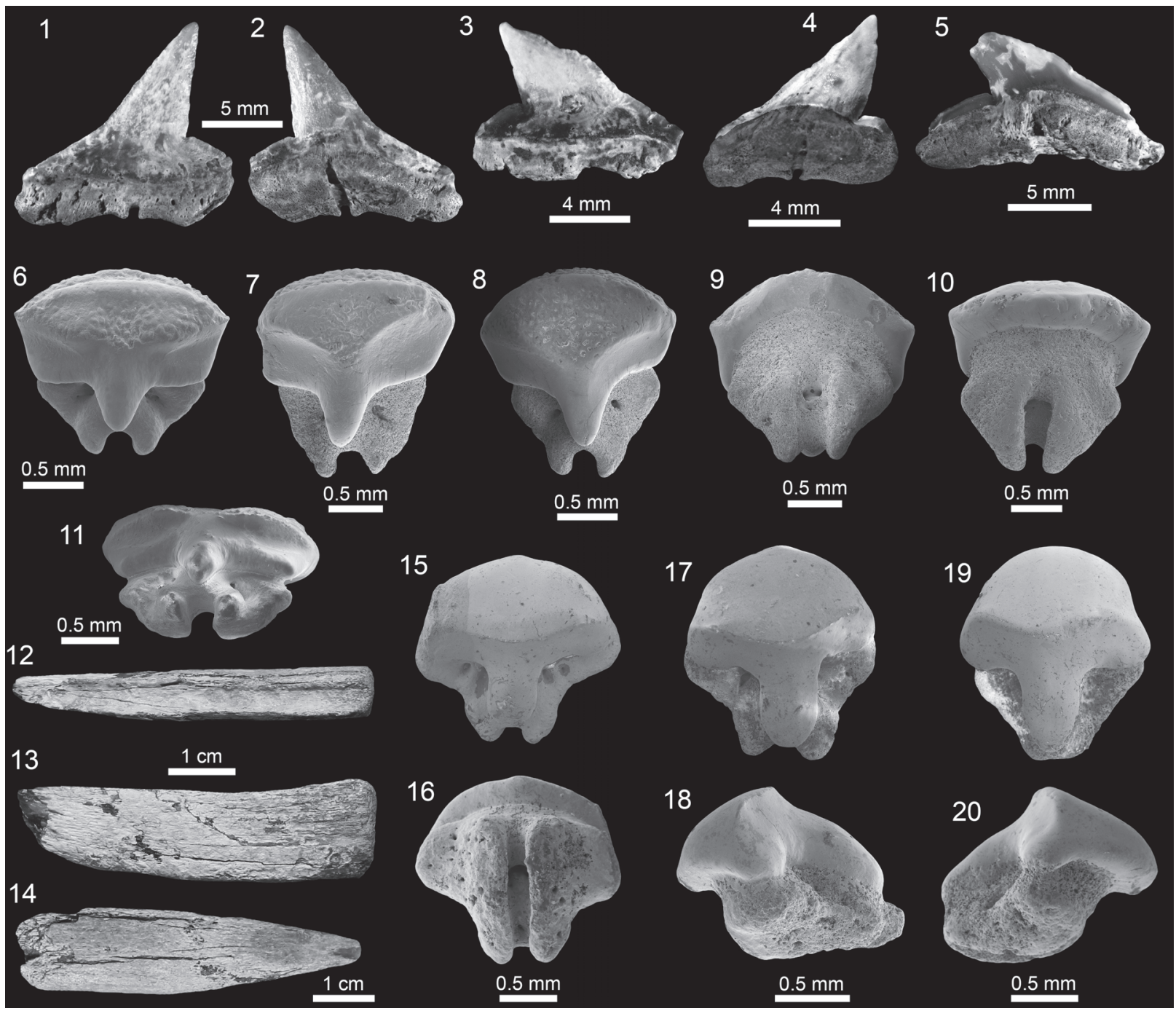

FIGURE 8. Carcharhiniformes and Rajiformes of the Cantaure Formation. 1-5. Sphyrna cf. †S. laevissima (1-3, 5: AMU-CURS-964 and 4: AMU-CURS-963). 6-11. Rhynchobatus sp. (6, 9: AMU-CURS-968; 7-8, 10: AMU-CURS-969 and 11: AMU-CURS-970). 12-20. Pristis sp. (rostral denticle 12-14: AMU-CURS-242; buccal teeth 15-20: AMUCURS-967). Jaw position: upper (1-2) and indet. (3-11, 15-20). View: labial (1, 3), lingual (2, 4-5, 11), occlusal (6-8, $15,17,19)$, profile $(18,20)$, basal $(9-10,16)$, posterior $(12)$ and dorsal $(13-14)$.

Rajiformes Berg, 1937. This group of batoids is represented by two families, two genera and two species (Figure 2). Concerning Rhynchobatidae Garman, 1913, we report indeterminate teeth of Rhynchobatus Müller and Henle 1837 (Figure 8.68.11; Appendix 1, 4), resembling previously figured isolated teeth of Rhynchobatus from the late Miocene of Costa Rica, Panama and Venezuela (Laurito, 1999; Pimiento et al., 2013b; Carrillo-Briceño et al., 2015b). We refrain from taxonomic identification at the species level of the Cantaure Rhynchobatus, because the range of dental variation in extant species is unknown, and little is known about fossil species from the Americas. The Pristi- dae Bonaparte, 1838 is represented by a few specimens of oral teeth and rostral denticles of Pristis Linck, 1790 (Figure 8.12-8.20, Appendix 1, 4). As noted by Carrillo-Briceño et al. (2015b), Pristis rostral denticles are not diagnostic at species level, while isolated oral teeth are somewhat difficult to identify, because those of extant species are poorly known and are morphologically diverse.

Myliobatiformes Compagno, 1973. This group is represented by four families, eight genera and 11 species, being thus the second most abundant and diverse order from the Cantaure assemblage (Figure 2; Table 1; Appendix 1, 4). The Dasyatidae Jordan, 1888 , is represented by three genera and four 


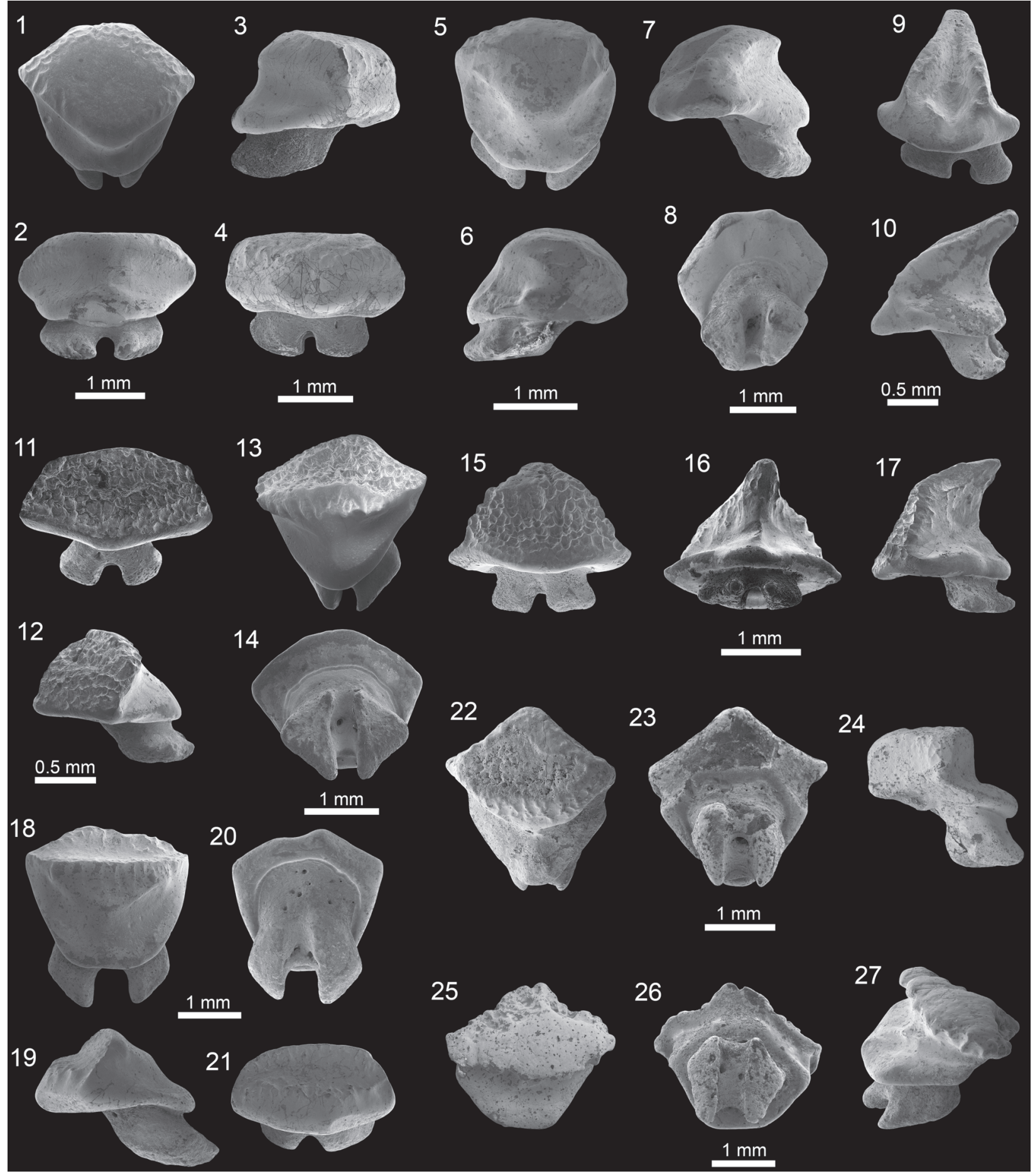

FIGURE 9. Myliobatiformes of the Cantaure Formation. 1-10. Dasyatis sp. (1-2, 7-8: AMU-CURS-930; 3-4: AMUCURS-932; 5-6: AMU-CURS-933 and 9-10: AMU-CURS-931). 11-17. cf. Pteroplatytrygon sp. (AMU-CURS-926). 1821. cf. Taeniurops sp. (AMU-CURS-925). 22-27. Dasyatidae indet. (22-24: AMU-CURS-936 and 25-27: AMU-CURS937). Jaw position: indet. (1-27). View: labial $(4,9,11,15,21)$, lingual $(2,16)$, occlusal $(1,5,13,18,22,25)$, profile (3, $6-7,10,12,17,19,24,27)$ and basal $(8,14,20,23,26)$. 


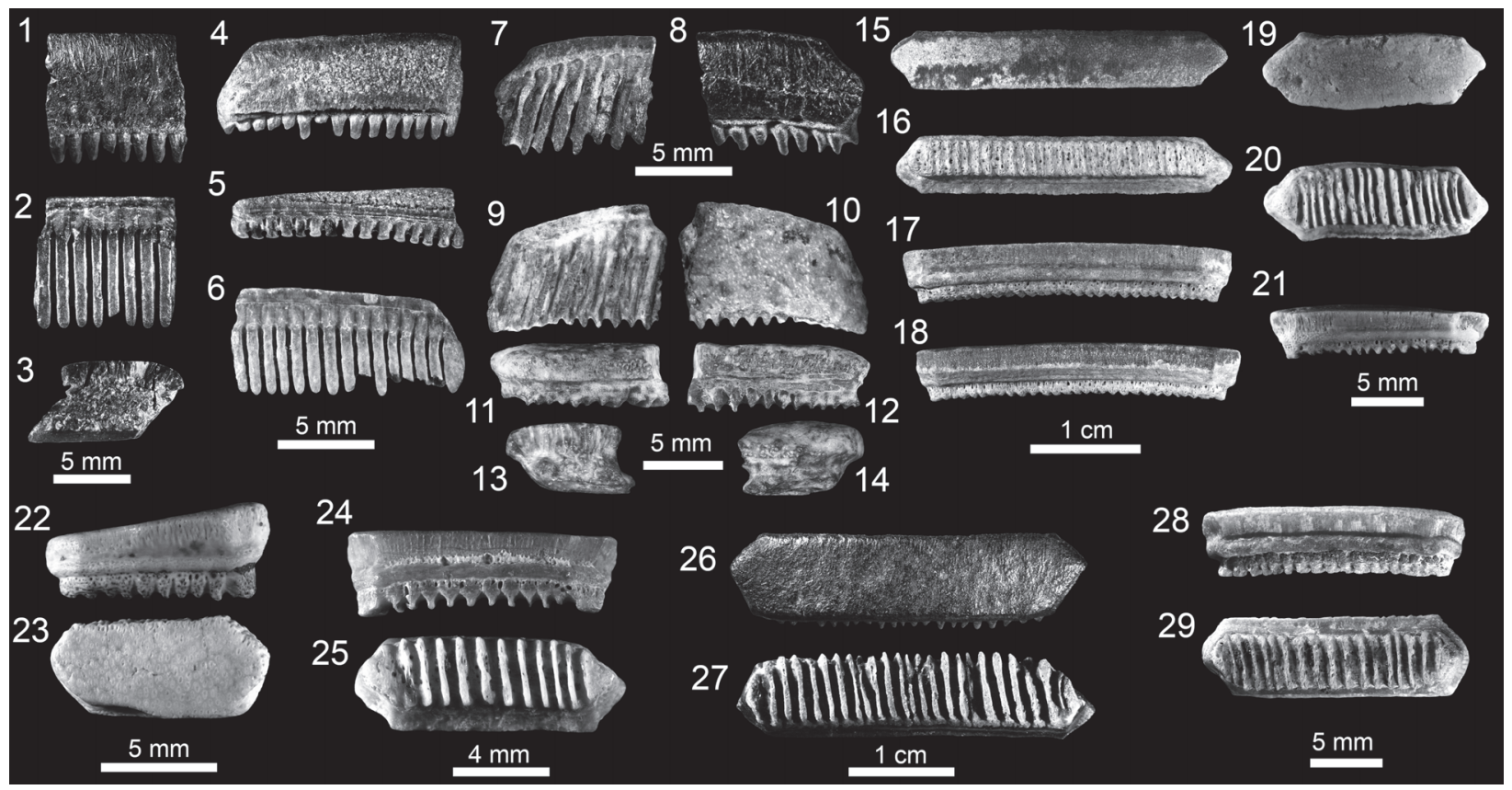

FIGURE 10. Myliobatiformes of the Cantaure Formation. 1-3. Aetobatus sp. (1-3: AMU-CURS-716). 4-14. Aetomylaeus sp. (AMU-CURS-750). 15-29. Rhinoptera sp. (15-18: AMU-CURS-979; 19-21, 22-23, 24-25, 28-29: AMU-CURS977 and 26-27: AMU-CURS-981). Jaw position: indet. (1-29). View: labial (11, 18), lingual (5, 12, 17, 21-22, 24, 28), occlusal $(1,4,8,10,15,19,23,26)$, profile $(3,13-14)$ and basal $(2,6,7,9,16,20,25,27,29)$.

species, and the Myliobatidae Bonaparte, 1838 and Rhinopteridae Jordan and Evermann, 1896 by one genus and one species each (Figure 2; Table 1). Due to the small number of specimens and the lack of diagnostic characters, teeth referred to Dasyatis Rafinesque, 1810 (Figure 9.1-9.10), cf. Pteroplatytrygon Fowler, 1910 (Figure 9.11-9.17), cf. Taeniurops Garman, 1913 (Figure 9.18-9.21), and Dasyatidae indet. (Figure 9.22-9.27), cannot be assigned to species. As noted by CarrilloBriceño et al. (2015b), there is very little known available about the morphological diversity of dental patterns in extant and fossil Dasyatidae from the Americas.

Teeth referred to Aetobatus Blainville, 1816 (Figure 10.1-10.3), and Aetomylaeus Garman, 1913 (Figure 10.4-10.14), are fragmented and incomplete; but preserve diagnostic characters that made their generic identification possible. Teeth of Rhinoptera Cuvier, 1829 (Figure 10.15-10.29) are common in all localities (especially at locality 2), being the third most abundant species of the assemblage (Appendix 1, 4). Previous work on the Cantaure Formation has reported the presence of Myliobatis Cuvier, 1816 teeth (Aguilera and Rodrigues de Aguilera, 2004; Aguilera and Lundberg, 2010; Aguilera, 2010). However, our revision of fossils led to the identification of isolated medial and lateral teeth, which exhibit the typical imbrication pattern and morphology of Rhinoptera. Mobulidae Gill, 1893 is represented by two genera and four species (Figure 2; Table 1; Appendix1, 4). The mobulids †Mobula fragilis Cappetta, 1970 (Figure 11.1-11.11), Mobula cf. †M. Ioupianensis Cappetta, 1970 (Figure 11.12-11.18) and Mobula sp. (Figure 11.19-11.23) are scarce (Appendix1, 4), and their teeth have been recovered from localities 1 and 2 only. One tooth of †Plinthicus stenodon Cope, 1869 was found at locality 3 .

All eroded, broken and non-diagnostic caudal spines (Figure 12.1-12.6) are referred to Myliobatiformes indet. In addition, specimens referred to Chondrichthyes indet. correspond to fragmented and non-diagnostic vertebrae (Figure 12.7-12.8).

\section{Elasmobranch Paleobathymetric Analysis}

The Cantaure elasmobranch fauna is characterized by a predominance of benthopelagic sharks and rays, the extant relatives of which inhabit diverse environments and have diverse bathymetric preferences, especially in neritic/epipelagic environments (Appendix 3). Our paleobathymetric analysis indicates that the most probable deposition depth for the Cantaure assemblage is the 0 to $50 \mathrm{~m}$ interval, followed by the 50 to $100 \mathrm{~m}$ interval as the second most probable (Figure 13). This sug- 


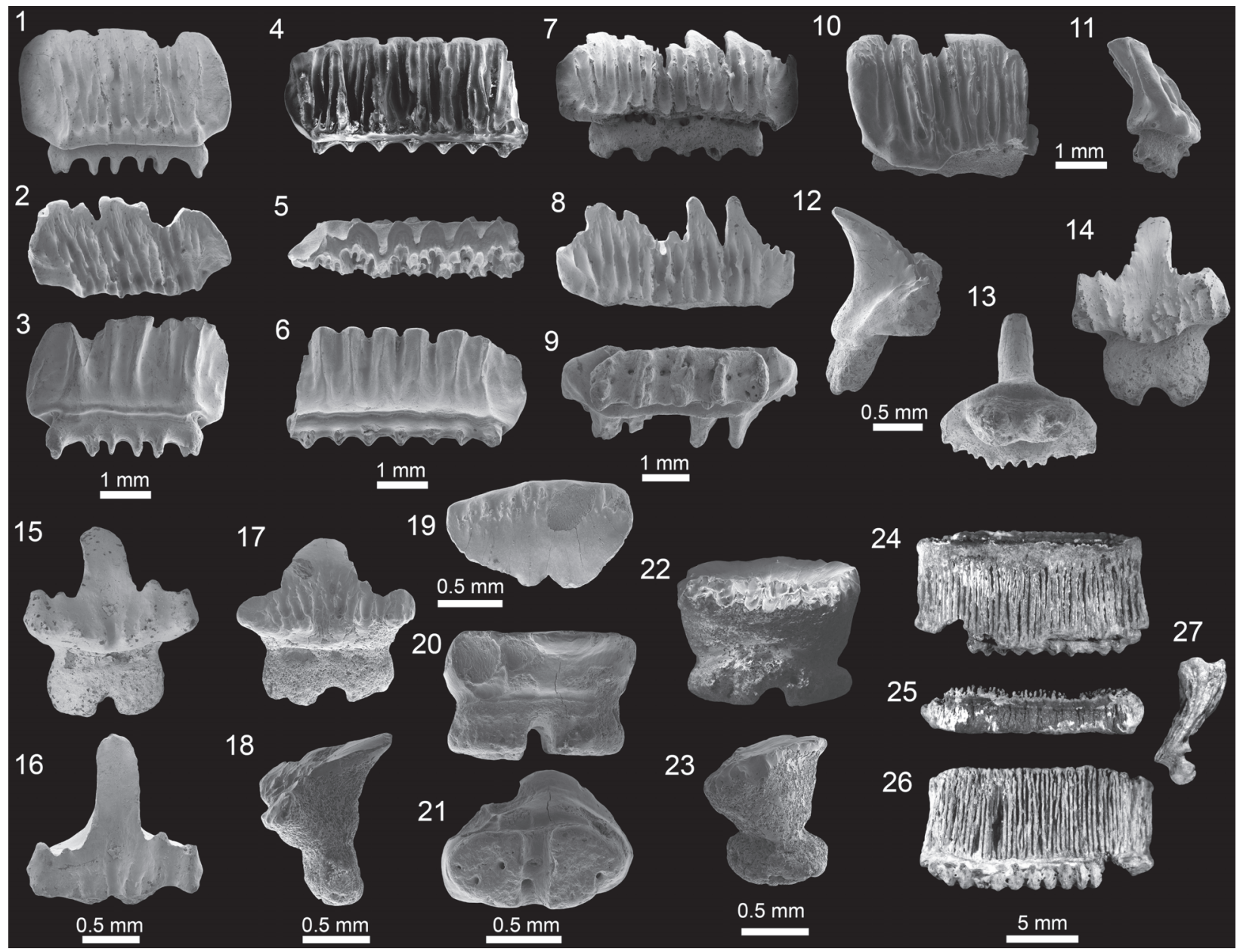

FIGURE 11. Mobulids of the Cantaure Formation. 1-11. †Mobula fragilis (1-3, 10-11: AMU-CURS-947; 4-6: AMUCURS-948 and 7-9: AMU-CURS-949). 12-18. Mobula cf. †M. loupianensis (AMU-CURS-946). 19-23. Mobula sp. (AMU-CURS-927). 24-27. †Plinthicus stenodon (AMU-CURS-715). Jaw position: indet. (1-27). View: labial (1, 4, 7, $10,14-15,17,22,24)$, lingual $(3,6,20,26)$, occlusal $(2,5,8,16,19,25)$, profile $(11-12,18,23,27)$ and basal $(9,13$, 21).

gests that the Cantaure Formation was deposited in an inner-middle shelf environment. The presence of Nebrius sp., Carcharhinus cf. C. limbatus, C. perezi, Isogomphodon acuarius, Negaprion eurybathrodon, Rhynchobatus sp. and Rhinoptera $\mathrm{sp}$. support this hypothesis, due to the fact that their extant representatives inhabit waters shallower than those of middle shelf environments (Appendix 3). Other taxa recognized in the first and second most probable depth intervals (Figure 13) include Alopiidae, Carcharhinidae, Sphyrnidae, Rinchobatidae, Pristidae, Dasyatidae, Myliobatidae and Mobulidae, whose extant representatives are associated with coastal environments. However, it is important to keep in mind that some of those species also have a wide vertical distributional range (Appendix 3 ), or are even able to move along significant distances over oceanic basins (Compagno, 1984b; Compagno et al., 2005; Voigt and Weber, 2011; Froese and Pauly, 2015).

\section{Dietary Preferences of the Cantaure Elasmobranchs}

The dietary composition of the elasmobranch assemblage from the Cantaure Formation can be represented by five food categories, from filter feeders to benthic-pelagic predators (Figure 14; Appendix 3). In this assemblage the most abundant feeder group is that of the piscivorous, representing $49 \%$ of the total species count (Figure 14; Appendix 3). We have included in this group the pelagic lamnid Paratodus benedenii (Cappetta, 1987, Kent and Powell, 1999) and the carcharhinid Physogaleus contortus, extinct species with a cut- 


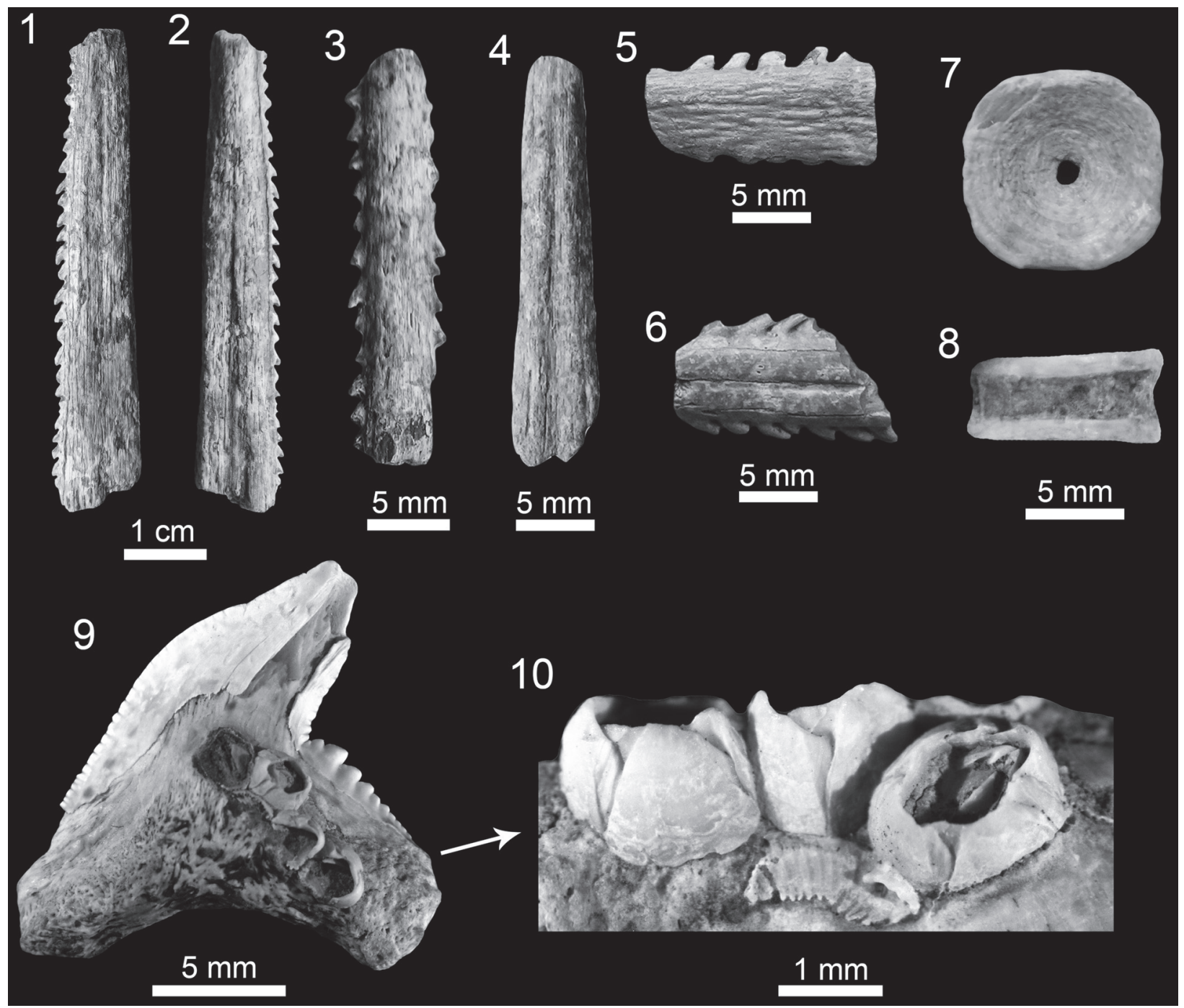

FIGURE 12. Myliobatiformes and other chondrichthyans of the Cantaure Formation. 1-6. Myliobatiformes indet. (AMU-CURS-507). 7-8. vertebra of chondrichthyan Indet. (AMU-CURS-928). 9-10. tooth of †Galeocerdo aduncus in association with barnacles of the family Balanidae (AMU-CURS-720). Jaw position: indet. (9). View: lingual (9), dorsal $(1,4,5-6)$, ventral (2-3) and indet. (7-8).

ting-clutching dental type that could suggest a fishbased diet. The durophagous/cancritrophic (mollusk, crustacean, coral feeders) group is the second most abundant, corresponding to $30 \%$ of the species in the Cantaure assemblage, with a predominance of Myliobatiformes and Rajiformes (Figure 14; Appendix 3). In this group the most abundant taxon is Rhinoptera sp., living species of which are opportunistic/generalists consuming mainly mollusks. The filter feeder group (Figure 14) is represented in the Cantaure assemblage only by mobulids (Table 1; Appendix 1, 4), whose living counterparts are characterized by a diet based mainly on planktonic microorganisms (Klimley,
2013). One of its representatives is the extinct mobulid Plinthicus stenodon, whose fragile teeth also suggest a possible filter diet of soft prey (Cappetta, 2012). In the eurytrophic/sarcophagous group (diverse food source: fishes, reptiles, birds, mammals, etc.) (Figure 14), we have included large sharks with a broad habitat preference. Those species include Carcharocles megalodon, Galeocerdo aduncus and G. mayumbensis, which could have had the role of apex predators. In reference to the teuthitrophic group, it is represented only by Alopias cf. A. vulpinus, whose living counterpart has a higher preference for cephalopods (Cortés, 1999; Appendix 3). 


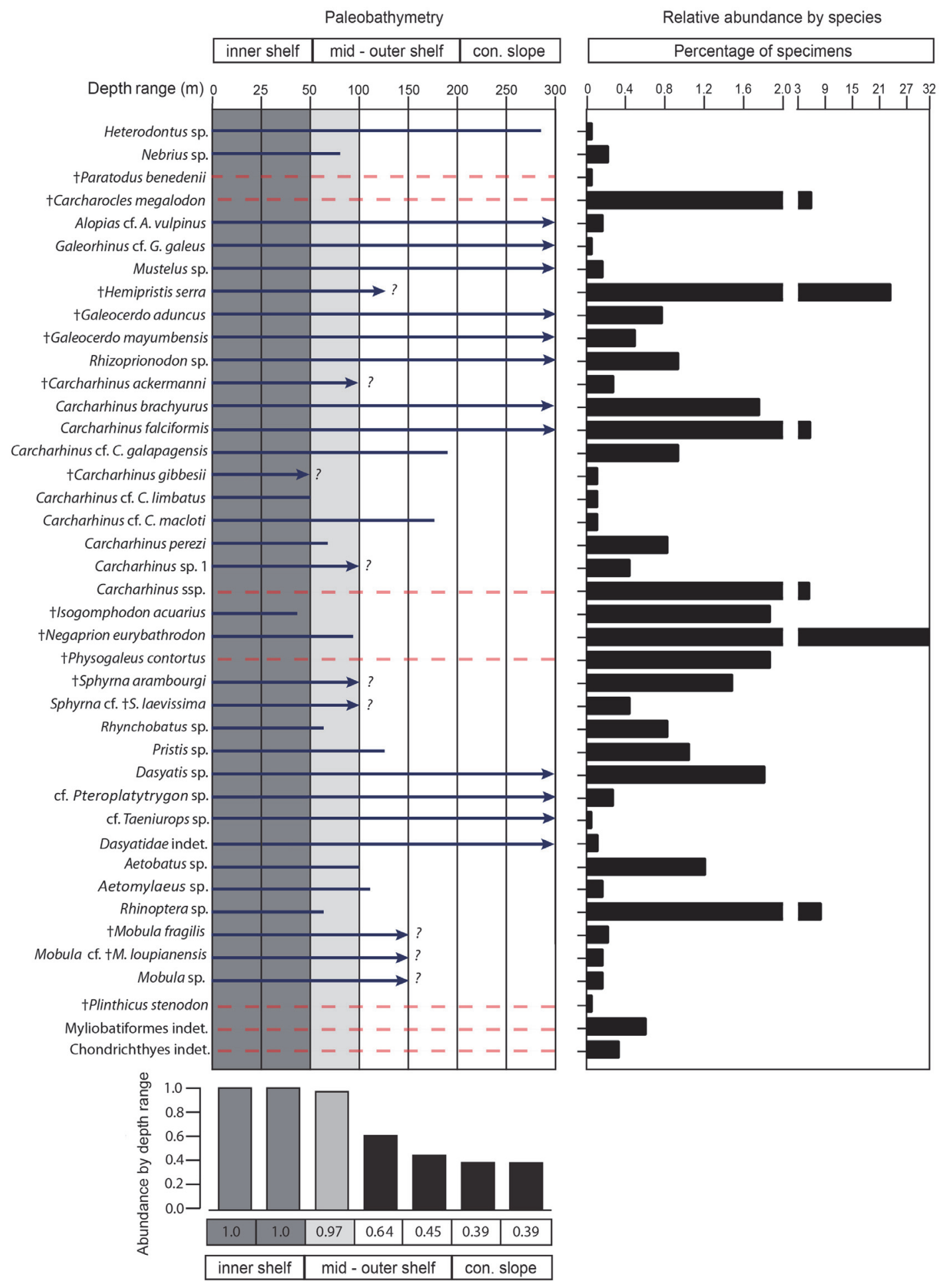

FIGURE 13. Bathymetric ranges estimated for Cantaure Formation taxa and their relative abundance. Arrows indicate that the bathymetric range is greater; question mark symbol indicates uncertainty about the extent of the range. A dashed red line indicates that there is no information for the taxa. The gray shadow indicates the more probably depth range for this assemblage. In the relative abundance graphic the $y$-axis is shortened between 2 and 3 to improve the values visualization; note the greater abundance of shallow water taxa. The extinct species including P. benedenii, C. megalodon, P. contortus, and P. stenodon, and taxa without clear identification, including Carcharhinus spp., Carcharhinidae indet., Myliobatiformes indet. and Chondrichthyes indet., were removed from the analysis. 


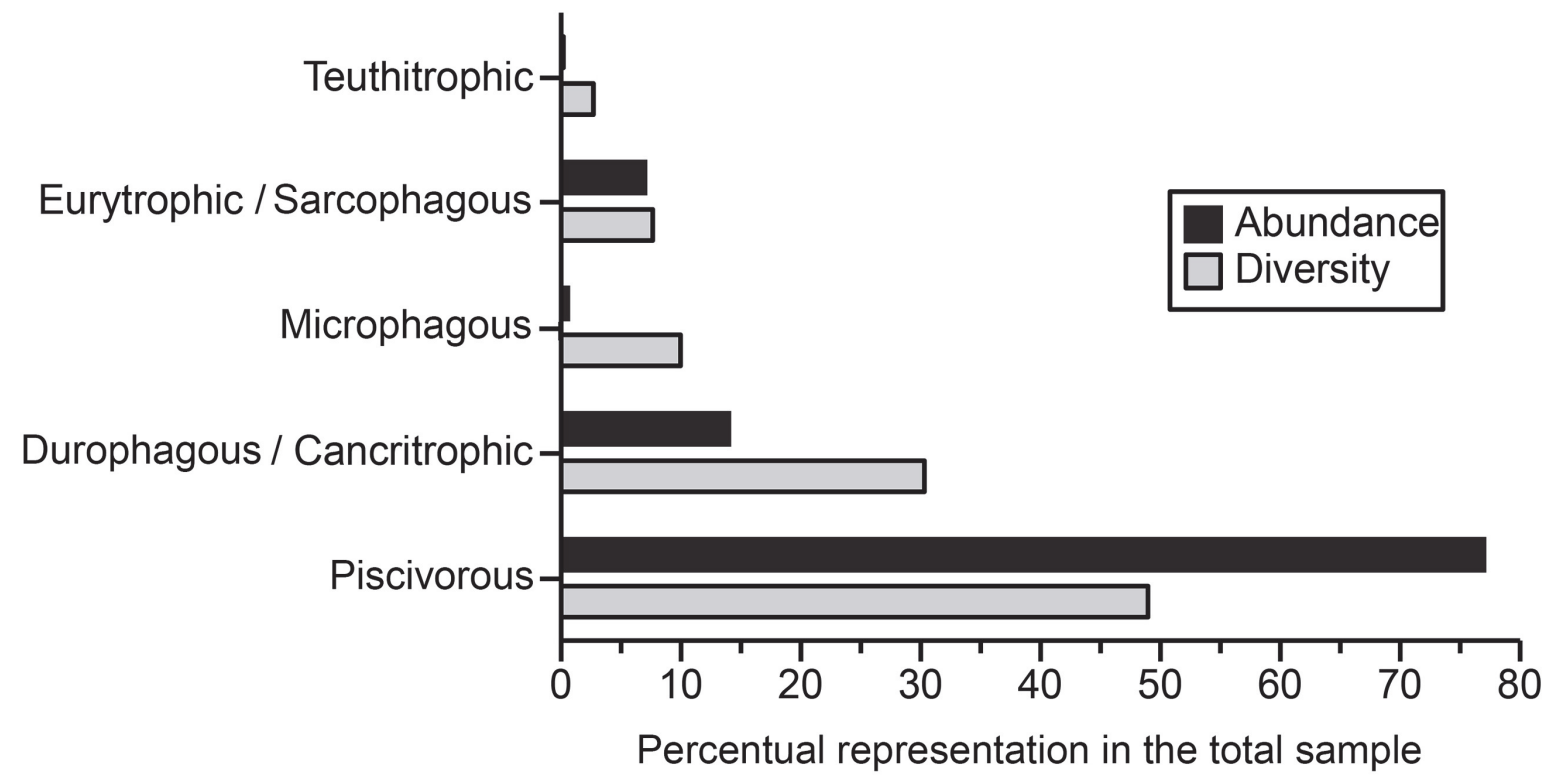

FIGURE 14. Dietary preference composition of the elasmobranchs from the Cantaure Formation. Percentages do not include Carcharhinus spp., Myliobatiformes indet. and Chondrichthyes indet.

\section{DISCUSSION}

\section{Paleodiversity Significance}

Forty-four percent of the Cantaure elasmobranch assemblage consists of genera or species with living representatives in Tropical America (Compagno, 1984a, 1984b; Compagno et al., 2005; Voigt and Weber, 2011). Five genera and 15 species present are extinct (Table 1). Nebrius sp., Carcharhinus cf. C. macloti, and Rhynchobatus sp., are present in our fossil sample and are currently extinct in the Caribbean, but have living counterparts in the eastern Atlantic and Indo-West Pacific (Compagno et al., 2005; Froese and Pauly, 2015). Their fossil record confirms that these taxa became extinct in the Caribbean, Western Atlantic and Eastern Pacific, possibly as a consequence of ecological competition with other species or environmental changes during the final stage of the CAS (e.g., Coates and Stallard, 2013).

The galeomorphs Paratodus benedenii, Galeocerdo mayumbensis, C. brachyurus, Carcharhinus cf. C. galapagensis, C. gibbesii, Carcharhinus cf. C. macloti, Isogomphodon acuarius, Physogaleus contortus, Sphyrna arambourgi, Sphyrna cf. S. laevissima, and the batoids cf. Pteroplatytrygon sp., cf. Taeniurops sp., Mobula fragilis and Mobula cf. M. loupianensis are reported for the first time from Neogene Venezuelan deposits. Paratodus benedenii, Carcharhinus cf. C. gala- pagensis, Carcharhinus cf. C. macloti, cf. Pteroplatytrygon sp, Taeniurops sp., Mobula fragilis and Mobula cf. M. loupianensis are new records for the Neogene of Tropical America. With the exception of the records mentioned above from Tropical America, the fossil record of most elasmobranch taxa from the Cantaure Formation have been found in other Neogene marine deposits of the Americas and are summarized in Kruckow and Thies (1990), Laurito (1999), Purdy et al. (2001), Aguilera et al. (2011), González-Rodríguez et al. (2013) and Carrillo-Briceño et al. (2014, 2015a, 2016).

Early Neogene marine elasmobranch assemblages known from the Americas are summarized in Figure 15 and include North America (Purdy et al., 2001; Visaggi and Godfrey, 2010), Southern South America (Suarez et al., 2006; Cione et al., 2011) and Tropical America (Leriche, 1938; Casier, 1966; MacPhee et al., 2003; Alván et al., 2006; Portell et al., 2008; Costa et al., 2009; Aguilera and Lundberg, 2010; Pimiento et al., 2013b, Laurito et al., 2014; Carrillo-Briceño et al., 2016). From these assemblages the Uitpa Formation (Colombia) has been referred to the Aquitanian (Carrillo-Briceño et al., 2016), while the Calvert and Pungo River formations in North America (Purdy et al., 2001; Visaggi and Godfrey, 2010) and the Cantaure (in this work) and Castillo (Rincón et al., 2014) formations in Venezuela, have been referred to the Burdiga- 


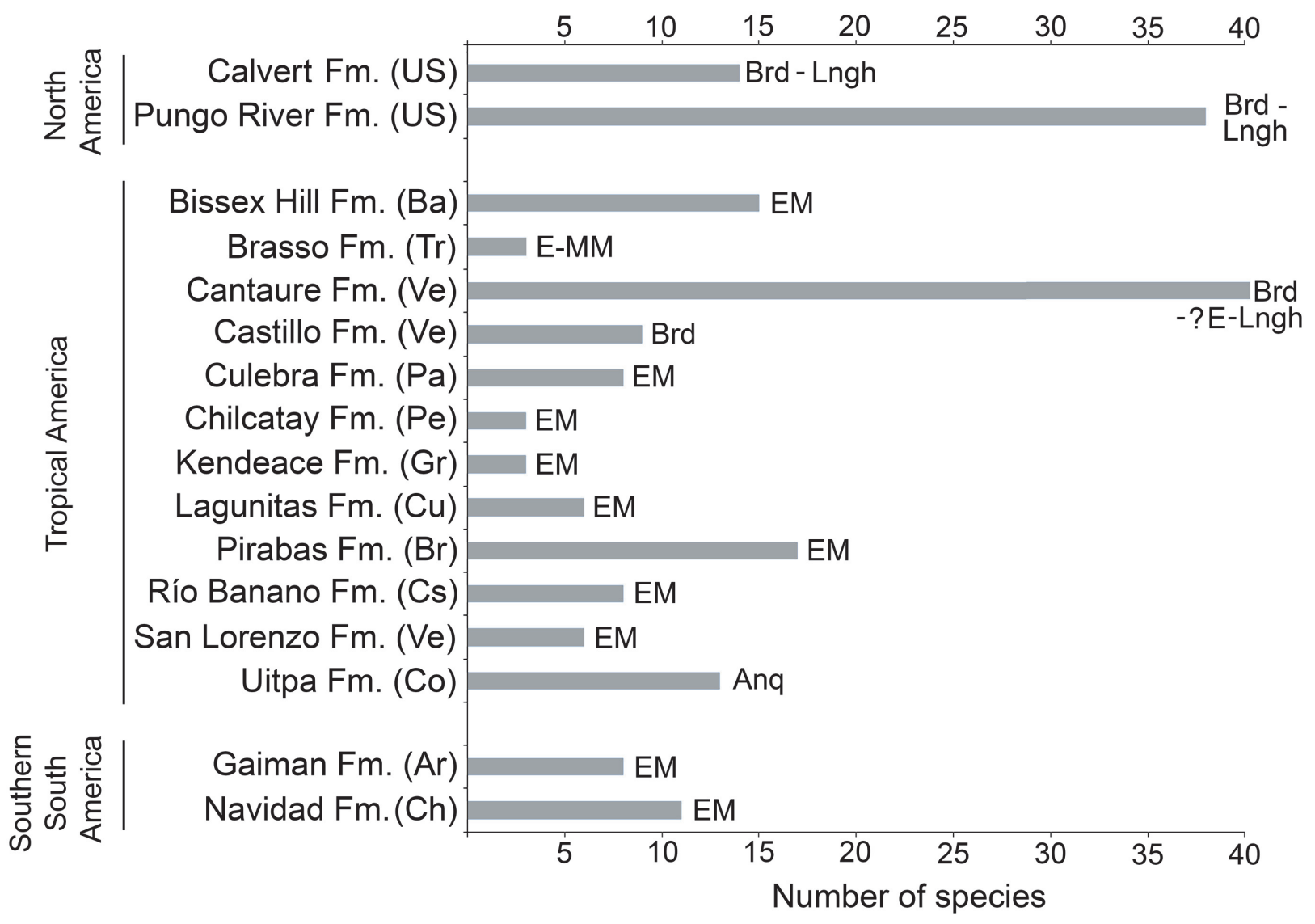

FIGURE 15. Early Neogene chondrichthyan diversity in the Americas. Tropical America: Barbados (Ba), Brazil (Br), Colombia (Co), Costa Rica (Cs), Cuba (Cu), The Grenadines (Gr), Panamá (Pa), Perú (Pu), Trinidad (Tr) and Venezuela (Ve). North America: United States of America (US). Southern South America: Argentina (Ar) and Chile (Ch). Aquitanian (Anq), Burdigalian (Brd), Langhian (Lngh); early Miocene without differentiation (EM), early-Middle Miocene (E$M M)$. Formation(Fm.), early (E). Note: to references see "Paleodiversity significance" (see Discusion).

lian. The remaining formations (Figure 15) have been assigned to an unresolved early Miocene age. The Pungo River ( 38 spp.) and Cantaure (39 spp.) assemblages preserve the most diverse elasmobranch faunas known from early Miocene of the Americas.

The late Burdigalian age ( $16.5 \pm 0.4 \mathrm{Ma}$.) of the Cantaure Formation based on $\mathrm{Sr}$ isotopes from corals from locality 2 of Griffiths et al. (2013) (Figure 1.2), suggests that all specimens found in localities 1 and 2 could be coetaneous or older than $16.5 \pm 0.4 \mathrm{Ma}$. The poorly known stratigraphic position of localities 3 and 4 , in reference to localities 1 and 2 (different vertical strata along the Cantaure section or horizontal variation of localities 1 and 2), does not permit an accurate age estimation for them, but their stratigraphic position (underlying the limestones interpreted as post-Cantaure sedimentation; Jung, 1965; Hunter and Bartok, 1974), suggests that these localities ( 3 and 4 ) are close to the top section of the Cantaure Formation. A Burdigalian age (Griffiths et al., 2013), or even that of a Burdigalian-Langhian boundary for the upper section of the Cantaure Formation (assuming that the biozones N7-8 and NN4-5 represent the lower to middle Miocene transition), would extend the stratigraphic range of two galeomorphs and of a batoid found in this assemblage. Fossils of Carcharhinus cf. C. galapagensis, from the Cantaure Formation, represent the oldest record for this species. It was previously known from the late Miocene of Mexico (González-Rodríguez et al., 2013). The same applies to Carcharhinus gibbesii, the youngest record was reported by Carrillo-Briceño et al. (2016) as the Aquitanian of Colombia. In reference to the batoid cf. Pteroplatytrygon sp., its record from the Cantaure Formation could be the oldest known to this stingray species. 
The presence of Carcharocles megalodon in Burdigalian sediments of the Cantaure Formation (in at least localities 1 and 2) confirms the presence of this species during late early Miocene. It has been generally accepted that the record of Carcharocles chubutensis spans from the early to the middle Miocene, whereas Carcharocles megalodon spans from the middle Miocene to the late Pliocene (Pimiento and Clements, 2014; Pimiento and Balk, 2015). However, other authors have suggested that $C$. megalodon also occurs in the Burdigalian of Europe and North America (Leriche, 1938; Purdy et al., 2001; Visaggi and Godfrey, 2010; Reinecke et al., 2011). According to Leriche (1938), the two C. megalodon specimens he collected (Leriche, 1938, Planche III, Figures 5-6) in southern Mexico (Tabasco and Isthmus of Tehuantepec) came from early Miocene strata and are similar to teeth he previously collected in the Burdigalian of Europe. Another early Miocene unpublished occurrence of $C$. megalodon from Tropical America is from the late Burdigalian section ( 16.2 Ma.) of the Castilletes Formation at North East Colombia (under study by JDCB). The specimens of $C$. megalodon from the Cantaure sequence have been found in all four localities studied here (Figure 1, Appendix 1), but with a greater abundance in localities 2 and 3 (Appendix 1). The presence of C. megalodon tooth (UNEFM-PF-322) at least 6-10 $\mathrm{m}$ deep in the artisan well (Figure 1.2) could suggest an older age than the $16.5 \pm 0.4 \mathrm{Ma}$ for the species. More detailed information about the American and worldwide Neogene stratigraphic range of the remaining elasmobranch taxa recovered from the Cantaure Formation (Table 1) can be found in Kruckow and Thies (1990), Cicimurri and Knight (2009), Reinecke et al. (2011), Bor et al. (2012), Adnet et al. (2012), Cappetta, (2012), Pimiento et al. (2013b), and Carrillo-Briceño et al. (2014, 2015a, 2016).

Furthermore, it is important to note that the elasmobranch fauna from the Cantaure Formation shows a clear differentiation in paleodiversity amongst the four localities studied here (Appendix 1, 4). As is shown in Appendix 4.2, localities 1 and 2 (Figure 1) have a higher diversity than those of localities 3 and 4 , a fact that could be attributable to: 1) less intensive sieving and sampling of the localities 3 and 4 (see Material and Methods section) or 2) different lithologic, taphonomic and preservational conditions. Future, more accurate dating of the deposits could offer new insights into the age of the Cantaure deposits, and especially of the sections located south of Barbasco Creek.

\section{Paleoenvironment and Paleoecology}

On the basis of planktonic foraminifera, calcareous nannofossils and mollusks, it has been proposed that the Cantaure Formation was deposited in a shallow, coastal tropical marine environment, with clear waters and normal salinity (Jung, 1965; Díaz de Gamero, 1974; Rey, 1996; Landau et al., in press). A conspicuous absence of typical herbivore gastropods suggests that sea-grass habitats were probably not represented in this environment (Landau et al., in press). The teleostean assemblage reported by Nolf and Aguilera (1998) reflects a shallow environment with a water depth of less than $50 \mathrm{~m}$. The crustacean assemblage (Aguilera et al., 2010) is also suggestive of innershelf environments. The barnacle epifauna attached to a shark tooth AMU-CURS-720 (Figure 12.9-12.10) further indicates that the Cantaure Formation was deposited in a shallow marine environment, as barnacles live either in intertidal $(26 \%)$ or sublittoral areas of $\leq 100 \mathrm{~m}(73 \%)$ (Doyle et al., 1996). Our bathymetric analysis of the Cantaure Formation, suggesting most likely an estimated deep interval depth between 0 to $50 \mathrm{~m}$ (Figure 13), supports the assumption of an inner-middle shelf environment (Figure 16). Additional support to this estimation is derived from the presence of the benthopelagic sharks Nebrius sp., Carcharhinus cf. C. limbatus, C. perezi and Isogomphodon acuarius, whose extant representatives usually prefer waters shallower than $40 \mathrm{~m}$ deep (Appendix 3). As shown in Figure 13, many of the benthopelagic and pelagic elasmobranch taxa of the Cantaure fauna have extant representatives associated with coastal environments, but can also occur in adjacent deep waters (Appendix 3), and even move significant distances over oceanic basins, suggesting a wide environmental range (Compagno et al., 2005; Voigt and Weber, 2011).

The Cantaure sequence rests on metamorphic and igneous rocks that were above water level during early Miocene (Gonzalez de Juana et al., 1980; Macellari, 1995). During the Cantaure sedimentation, these positive reliefs played the role of islands or archipelagos, as illustrated in the paleogeographic reconstruction of the Falcon Basin by Gonzalez de Juana et al. (1980) and Macellari (1995). According to Landau et al. (in press), $47.8 \%$ of the gastropod species (188 spp.) in the Cantaure Formation are exclusive, representing a very high level of endemism. This species endemism could support the hypothesis of an isolated, insular mollusk-community in the northern part of the Falcon Basin during early Miocene. However, 


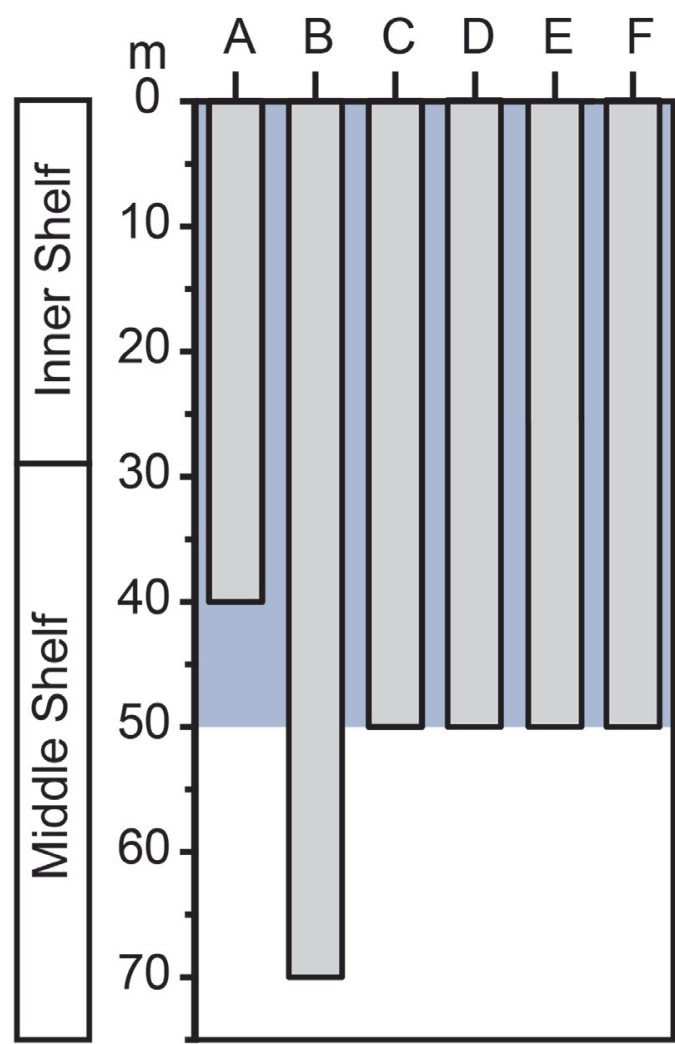

FIGURE 16. Paleobathymetric interpretation of the Cantaure Formation using several proxies. A, Foraminifera (Díaz de Gamero, 1974), B, corals (Griffiths et al., 2013), C, mollusks (Jung, 1965; Landau et al., in press), D, crustaceans (Aguilera et al., 2010), E, sharks (this study), F, teleosteans (Nolf and Aguilera, 1998, Aguilera and Rodrigues de Aguilera, 2001).

expanded knowledge of their localities will certainly lower that estimate. The Cantaure gastropod assemblage also has a small freshwater component, corresponding to typical species of late Oligocene early Middle Miocene NW South-American inland freshwater faunas (Landau et al. in press). This is likely suggestive of insular areas allowing the existence of terrestrial faunas. In addition, the diverse teleostean fauna from the Cantaure Formation, with more than 65 species (Nolf and Aguilera, 1998; Aguilera, 2010; Aguilera and Lundberg, 2010), suggests a high-productivity environment associated with a coastal upwelling (Aguilera and Rodrigues de Aguilera, 2004).

Although it is difficult to approach the precise ecological role that the Cantaure elasmobranch fauna played in this ancient marine environment, we can speculate about trophic interactions using the dietary (nutrition mode) categorization of taxa in the assemblage (Figure 14). The Cantaure assemblage is dominated by piscivorous shark species (Figure 14, Appendix, 3). This could be related to the diverse teleostean fauna of the Cantaure Formation (Nolf and Aguilera, 1998; Aguilera, 2010; Aguilera and Lundberg, 2010), whose remains (mainly otoliths) are extremely abundant, with approximately more than 60 specimens per 10 $\mathrm{kg}$ of sifted matrix (OAA and JDCB pers. obs.). The durophagous/cancritrophic feeders represent the second most abundant elasmobranch group in the assemblage (Figure 14, Appendix 3). Their potential benthonic prey includes some 445 mollusks species (Jackson et al., 1999; Landau et al., in press) and more than 20 crustacean species (Aguilera et al., 2010) and must have offered wide feeding opportunities. Durophagous rays with capacity to triturate hard shells were abundant in the Cantaure fauna (e.g., Rhinoptera sp. being the third most abundant species of the assemblage, Appendix 1,3). The presence of mobulids (Table 1, Appendix 1,4), whose living counterparts are characterized by a diet based mainly on planktonic microorganisms (Klimley, 2013), support the assumption of a high-productive environment associated to a coastal upwelling (Aguilera and Rodrigues de Aguilera, 2004).

A few large sharks from the Cantaure assemblage such as Carcharocles megalodon, Galeocerdo aduncus and G. mayumbensis, could have alternatively occupied different environments and fed on various resources, such as teleosteans, chondrichthyans, reptiles, birds and mammals. In extant marine communities many sharks are perceived as apex predators, occupying the same trophic level with marine mammals (Klimley, 2013). In the Cantaure fauna such large sharks (C. megalodon, G. aduncus and G. mayumbensis), together with a medium-sized odontocete (?Squalodelphinidae) (Cozzuol and Aguilera, 2008; likely occupied the apex predator role. Moreover, cetacean (squalodontids) and sirenid (dugongids) skeletal remains found in the Cantaure Formation exhibit shark bite marks, suggesting that these mammals also were prey (Cozzuol and Aguilera, 2008). A cetacean lumbar vertebra with an embedded tooth of a Carcharocles megalodon was reported from the early Pliocene Paraguaná Formation, in the "El Yacural" locality (Aguilera et al., 2008). Recent field work in the "El Yacural" produced new specimens that include cetacean remains (vertebra and a skull fragment; AMU-CURS-709 and 710, respectively) and a crocodilian vertebra (AMU-CURS-708).

Those specimens lack any evidence for predation. The geographic coordinates of locality 4 
(Figure 1.1) are very close to the "El Yacural" locality studied by Aguilera et al. (2008), with a horizontal distance of less than $200 \mathrm{~m}$. Both localities are overlain stratigraphically by limestone layers on the top of the Cerro San Carlos (OAA, JDCB, GAF, pers. obs.), which have been interpreted by Jung (1965) and Hunter and Bartok (1974) as the top of the Cantaure Formation, representing the transition between the latter unit and post-Cantaure and pre-Pliocene sedimentation. We tentatively suggest that the vertebra with an embedded Carcharocles megalodon tooth could belong to the Cantaure Formation and not to the early Pliocene Paraguaná Formation (Aguilera et al., 2008). As previously mentioned, the Cantaure Formation is a complex sequence that needs a new detailed stratigraphic redescription, which could offer new geological information. The sections located at the south of the Barbasco Creek are of particular relevance for future research. In addition, the crocodilian vertebra (AMU-CURS-708) and the small eroded turtleshell fragments, although not offering useful information for taxonomical classification, verify the presence of at least two reptiles in this ancient high-productive marine environment of the Cantaure Formation.

\section{CONCLUSIONS}

The elasmobranch fauna from the Cantaure Formation, containing 39 species, is characterized by a predominance of benthopelagic sharks with piscivorous feeding preferences, followed by durophagous/cancritrophic feeders. The elasmobranch habitat preferences and paleobathymetric analyses support the hypothesis that the Cantaure Formation was deposited in a high productivity, inner-middle shelf environment, around positive reliefs (island/archipelago), in the northern part of Falcon Basin during early-?middle Miocene. This shark and ray fauna, is one of most diverse assemblages from early Neogene of the Americas, and contains many forms now extinct in the Caribbean, but present in the eastern Atlantic and western Pacific. Crocodile and turtle remains are also preserved in the Cantaure Formation.

\section{ACKNOWLEDGEMENTS}

This work was supported by Swiss National Science Foundation SNF 31003A-149605 to MRSV and by the Smithsonian Tropical Research Institute (Panama Paleontological Project) to OAA. The authors wish to especially thank T. Argyriou, B. Landau, J. Reyes, D. Rodrigues de Aguilera, A.
Coates, Dr. H. Cappetta, S. Adnet, R. Sánchez, C. Moron, H. Moreno, I. de Jesus, D. Cruz and A.E. Reyes for their generous and important counseling and collaboration; the Instituto del Patrimonio Cultural de Venezuela, for the authorization and permissions to collect, transport and study fossil material. Special thanks to R. Roth, M. Kirschmann and the Center for Microscopy and Image Analysis of the University of Zurich for their assistance and support performing the scanning electron microscopy analysis. The Alcaldía Bolivariana de Urumaco, the Universidad Experimental Francisco de Miranda, Museo de Ciencias Naturales de Caracas in Venezuela; Mapuka Museum of Universidad del Norte (Barranquilla, Colombia), Universidade Federal Fluminense, Universidade Federal do Pará and Museu Paraense Emilio Goeldi (Brazil), Natural History Museum of Basel (Switzerland), Paleontological collection of the Institut des Sciences de l'Evolution, University of Montpellier (France) and Palaeontological Institute and Museum at the University of Zurich for their valuable assistance and for access to comparative material. We greatly appreciate comments and suggestions from two anonymous reviewers.

\section{REFERENCES}

Adnet, S., Cappetta, H., Guinot, G., and Notarbartolo Di Sciara, G. 2012. Evolutionary history of the devilrays (Chondrichthyes: Myliobatiformes) from fossil and morphological inference. Zoological Journal of the Linnean Society, 166(1):132-159.

Agassiz, L. 1833-1843. Recherches sur les poisons fossils, 3, Neuchatel.

Aguilera, O.A. 2010. Peces Fósiles del Caribe de Venezuela. Gorham Printing, Washington.

Aguilera, O.A. and Rodrigues de Aguilera, D. 2004. Giant-toothed white sharks and wide-toothed mako (Lamnidae) from the Venezuela Neogene: Their role in the Caribbean, shallow-water fish Assemblage. Caribbean Journal of Science, 40(3):368-382.

Aguilera, O.A. and Lundberg, J.G. 2010. Venezuelan Caribbean and Orinocoan Neogene fish, p. 129-152. In Sánchez-Villagra, M.R., Aguilera, O.A., and Carlini, F. (eds.), Urumaco and Venezuelan Paleontology. Indiana Press University, Bloomington.

Aguilera, O.A., García, L., and Cozzuol, M. 2008. Gianttoothed white sharks and cetacean trophic interaction from the Pliocene Caribbean Paraguaná Formation. Paläontologische Zeitschrift, 82(2):204-208.

Aguilera, O.A., Rodrigues de Aguilera, D., Vega, F.J., and Sánchez-Villagra, M.R. 2010. Mesozoic and Cenozoic decapod crustaceans from Venezuela and related trace-fossil assemblages, p. 103-128. In Sánchez-Villagra, M.R., Aguilera, O.A., and Carlini, 
F. (eds.), Urumaco and Venezuelan Paleontology. Indiana Press University, Bloomington.

Aguilera, O.A., Ramos, M.I.F., Paes, E.T., Costa, S.A.R.F., and Sánchez-Villagra, M.R. 2011. The Neogene tropical America fish assemblage and the paleobiogeography of the Caribbean region. Swiss Journal of Palaeontology, 130(2):217-240.

Alván, A., Apolín, J., and Chacaltana, C. 2006. Los dientes de seláceos (Chondrichthyes) y su aplicación estratigráfica en la lomas de Ullujaya (Ica-Perú). In: XIII Congreso Peruano de Geología, Lima, 17-20 octubre, 2006:595-598.

Ameghino, F. 1901. L'âge des formations sédimentaires de Patagonie. Anales de la Sociedad Científica Argentina, 51:20-39, 65-91.

Applegate, S.P. 1972. A revision of the higher taxa of Orectoloboids. Journal of the Marine Biological Association of India, 14(2):743-751.

Berg, L.S. 1937. A classification of fish-like vertebrates. Bulletin of the Academy of Sciences of the USSR, Division of Chemical Science, 1937:1277-1280.

Blainville, H.M.D. 1816. Prodrome d'une nouvelle distribution systematique du regne animal. Bulletin de la Société Philomathique de Paris, 8:105-112, 121-124.

Blake, C.C. 1862. Shark's teeth at Panama. Geologist, 5:316.

Bonaparte, C.L. 1838. Selachorum tabula analytica. Nuovi Annali della Science Naturali Bologna, 1:195214.

Bonnaterre, J.P. 1788. Ichthyologie. Tableau encyclopédique et méthodique des trois règnes de la nature, Paris.

Bor, T.J., Reinecke, T., and Verschueren, S. 2012. Miocene Chondrichthyes from Winterswijk - Miste, the Netherlands. Palaeontos, 21:1-136.

Cappetta, H. 1970. Les Sélaciens du Miocène de la région de Montpellier. Palaeovertebrata, Mémoire Extraordinaire, (1970):1-139.

Cappetta, H. 1980. Modification du satut generique de queleques especes de sélaciens crétacés et tertiares. Palaeovertebrata, 10:29-42.

Cappetta, H. 1987. Chondrichthyes II: Mesozoic and Cenozoic Elasmobranchii. Handbook of Paleoichthyology, 3B. Verlag Dr. Friedrich Pfeil, Munich.

Cappetta, H. 2012. Chondrichthyes. Mesozoic and Cenozoic Elasmobranchii: Teeth. Handbook of Paleoichthyology, 3E. Verlag Dr. Friedrich Pfeil, Munich.

Carrillo-Briceño, J.D., Aguilera, O.A., and Rodríguez, F. 2014. Fossil Chondrichthyes from the central eastern Pacific Ocean and their paleoceanographic significance. Journal of South American Earth Sciences, 51:76-90.

Carrillo-Briceño, J.D., De Gracia, C., Pimiento, C., Aguilera, O.A., Kindlimann, R., Santamarina, P., and Jaramillo, C. 2015a. A new Late Miocene chondrichthyan assemblage from the Chagres Formation, Panama. Journal of South American Earth Sciences, 60:56-70.
Carrillo-Briceño, J.D., Maxwell, E., Aguilera, O.A., Sánchez, R., and Sánchez-Villagra M.R. 2015b. Sawfishes and other elasmobranch assemblages from the Mio-Pliocene of the south Caribbean (Urumaco Sequence, Northwestern Venezuela). PLOS ONE, 10(10):e0139230. doi:10.1371/journal.pone.0139230.

Carrillo-Briceño, J.D., Argyriou, T., Zapata, V., Kindlimann, R., and Jaramillo, C.A. 2016. A new Early Miocene (Aquitanian) Elasmobranchii assemblage from the Guajira peninsula, Colombia. Ameghiniana, 53:77-99.

Casier, E. 1958. Contribution á l'étude des poissons fossiles des Antilles. Mémoire Suisse de Paléontologie, 74:1-95.

Casier, E. 1966. Sur la faune ichthyologique de la Formation de Bissex Hill et de la Série océanique, de l'lle de la Barbade, et sur l'âge de ces formations. Eclogae Geologicae Helvetiae, 59:493-516.

Cicimurri, D.J. and Knight, J.L. 2009. Late Oligocene sharks and rays from the Chandler Bridge Formation, Dorchester County, South Carolina, USA. Acta Palaeontologica Polonica, 54(4):627-647.

Cione, A.L., Cozzuol, M.A., Dozo, M.T., and Acosta Hospitaleche, C. 2011. Marine vertebrate assemblages in the southwest Atlantic during the Miocene. Biological Journal of the Linnean Society, 103(2):423-440.

Coates, A.G. and Stallard, R.F. 2013. How old is the Isthmus of Panama? Bulletin of Marine Sciences, 89(4):801-813.

Compagno, L.J.V. 1973. Interrelationships of living elasmobranchs, p. 15-61. In Greenwood, P.H., Miles, R.S., and Patterson, C. (eds.), Interrelationships of Fishes. Academic Press, London.

Compagno, L.J.V. 1984a. Sharks of the World: An Annotated and Illustrated Catalogue of Shark Species Known to Date. Part 1: Hexanchiformes to Lamniformes. FAO Species Catalogue, 4. Food and Agriculture Organization of the United Nations, Rome.

Compagno, L.J.V. 1984b. Sharks of the World. An Annotated and Illustrated Catalogue of Shark Species Known to Date. Part 2: Carcharhiniformes. FAO Species Catalogue, 4. Food and Agriculture Organization of the United Nations, Rome.

Compagno, L.J.V. 2005. Appendix 1: Global Checklist of Living Fishes. Sharks, Rays and Chimaeras: The Status of the Chondrichthyan Fishes. IUCN-The World Conservation Union, Oxford, UK.

Compagno, L.J.V., Dando, M., and Fowler, S. 2005. Sharks of the World. Princeton University Press, Princeton.

Cope, E.D. 1867. An addition to the vertebrate fauna of the Miocene period, with a synopsis of the extinct Cetacea of the United States. Proceedings of the Academy of Natural Sciences of Philadelphia, 19:138-156.

Cope, E.D. 1869. Descriptions of some extinct fishes previously unknown. Proceedings of the Boston Society of Natural History, 12:310-317. 
Cortés, E. 1999. Standardized diet compositions and trophic levels of sharks. ICES Journal of Marine Science, 56:707-717.

Cortés, E., Papastamatiou, Y.P., Carlson, J.K., FerryGraham, L., and Wetherbee, B.M. 2008. An overview of the feeding ecology and physiology of elasmobranch fishes, p. 393-443. In Cyrino, J.E.P., Bureau, D.P., and Kapoor, B.G. (eds.), Feeding and Digestive Functions of Fishes. Taylor and Francis Group, Florida.

Costa, S.A.F., Richter, M., Toledo, P.M., and MoraesSantos, H.M. 2009. Shark teeth from Pirabas Formation (Lower Miocene), northeastern Amazonia, Brazil. Boletin do Museo Paraense Emílio Goeldi, Ciencias Naturais, 4:221-230.

Cozzuol, M.A. and Aguilera, O.A. 2008. Cetacean remains from the Neogene of northwestern Venezuela. Paläontologische Zeitschrift, 82(2):196-203.

Cuvier, G.L.C.F.D. 1816. Le Règne Animal distribué d'après son organisation pour servir de base à I'histoire naturelle des animaux et d'introduction à l'anatomie comparée. Les reptiles, les poissons, les mollusques et les annélides. Deterville, Paris.

Cuvier, G.L.C.F.D. 1829. Le règne animal, distribué d'après son organisation, pour servir de base à l'histoire naturelle des animaux et d'introduction à l'anatomie comparée. Chez Deéterville, Paris.

Daimeries, A. 1889. Notes ichthyologiques. V. Annales de la Société royale malacologique de Belgique. Bulletin des Séances, 24:39-44.

Dartevelle, E. and Casier, E. 1943. Les poissons fossiles du Bas-Congo et des régions voisines. Annales $d u$ Musée du Congo Belge, Série. A (Minéralogie Géologie, Paléontologie), 2(1):1-200.

Díaz de Gamero, M.L. 1974. Microfauna y edad de la Formación Cantaure, Península de Paraguaná, Venezuela. Boletín Informativo, Asociación Venezolana de Geología, 17:41-47.

Doyle, P., Mather, A.E., Bennett, M.R., and Bussell, M.A. 1996. Miocene barnacle assemblages from southern Spain and their palaeoenvironmental significance. Lethaia, 29(3):267-274.

Ebert, D.A. and Stehmann, M.F.W. 2013. Sharks, Batoids, and Chimaeras of the North Atlantic. FAO Species Catalogue for Fishery Purposes, 7. Food and Agriculture Organization of the United Nations, Rome.

Fowler, H.W. 1910. Notes on batoid fishes. Proceedings of the Academy of Natural Sciences of Philadelphia, 62:468-475.

Froese, R. and Pauly, D. 2015. FishBase. World Wide Web electronic publication. www.fishbase.org, version (2015).

Garman, S. 1913. The Plagiostomia (Sharks, Skates and Rays). Memoirs of the Museum of Comparative Zoology at Harvard College, 36:1-528.

Gibbes, R.W. 1849. Monograph of the fossil Squalidae of the United States. Journal of the Academy of Natural Sciences of Philadelphia, 1(2):191-206.
Gibson-Smith, J. 1974. On two new members of the family Ovulidae (Mollusca: Gasterópoda) from the Cantaure Formation, Venezuela. Boletín Informativo, Asociación Venezolana de Geología, Minería y Petróleo, 17(4-6):87-89.

Gibson-Smith, J. and Gibson-Smith, W. 1974. The Genus Strombina in Venezuela, with description of a new Recent and some fossil species. Boletín Informativo, Asociación Venezolana de Geología, Minería y Petróleo, 17(4-6):49-85.

Gill, T. 1862. Note on some genera of fishes of western North America. Proceedings of the Academy of Natural Sciences of Philadelphia, 14:329-332.

Gill, T. 1872. Arrangement of the Families of Fishes or Classes Pisces, Marsipobranchii, and Leptocardii Prepared for the Smithsonian Institution by Theodore Gill, 247. Smithsonian Institution Miscellaneous Collection.

Gill, T. 1893. Families and subfamilies of fishes. Memoirs of the National Academy of Sciences, 6:125-138.

Glikman, L.S. 1964. Sharks of the Paleogene and Their Stratigraphic Significance. Nauka Press, Moscow. (In Russian).

González de Juana, C., Iturralde de Arozena, J.M., and Picard, C.X. 1980. Geología de Venezuela y de sus Cuencas Petrolíferas. Ediciones Foninves, Caracas.

González-Rodríguez, K.A., Espinosa-Arrubarrena, L., and González-Barba, G. 2013. An overview of the Mexican fossil fish record, p. 9-34. In Arratia, G., Schultze, H.P., and Wilson, M.V.H. (eds.), Mesozoic Fishes 5 - Global Diversity and Evolution. Verlag Dr. Friedrich Pfeil, München, Germany.

Gradstein, F.M., Ogg, J.G., Schmitz, M.D., and Ogg, G. 2012. The Geologic Time Scale 2012. Elsevier New York, pp. 437-1144.

Gray, J. 1851. List of the specimens of fish in the collection of the British Museum. Part 1. Chondropterygii. British Museum (Natural History).

Griffiths, N., Müller, W., Johnson, K.G., and Aguilera, O.A. 2013. Evaluation of the effect of diagenetic cements on element/Ca ratios in aragonitic Early Miocene ( $16 \mathrm{Ma}$ ) Caribbean corals: Implications for 'deep-time' palaeo-environmental reconstructions. Palaeogeography, Palaeoclimatology, Palaeoecology, 369:185-200.

Günther, A. 1870. Catalogue of the Fishes in the British Museum, 8. British Museum (Natural History), London.

Hasse, K.E. 1879. Das natürliche System der Elasmobranchier auf Grundlage des Baues und der Entwicklung ihrer Wirbelsäule: eine morphologische und paläontologische Studie, 1. Gustav Fischer Verlag, Jena.

Hunter, V.F. and Bartok, P. 1974. The age and correlation of the Tertiary sediments of the Paraguaná Península, Venezuela. Boletín Informativo, Asociación Venezolana de Geología, Minería y Petróleo, 17:143154. 
Ingram, W.M. 1947. New fossil Cypraeidae from Venezuela and Colombia. Bulletins of American Paleontology, 31(121):1-12.

Iturralde-Vinent, M.A., Hubbell, G., and Rojas, R. 1996. Catalogue of Cuban fossil Elasmobranchii (Paleocene to Pliocene) and paleogeographic implications of their lower to middle Miocene occurrence. Boletín de la Sociedad Jamaicana de Geología, 31:7-21.

Jackson, J.B.C., Todd, J.A., Fortunato, H., and Jung, P. 1999. Diversity and assemblages of Neogene Caribbean Mollusca of lower Central America, p. 193-230. In Collins, L.S. and Coates, A.G. (eds.), A Paleobiotic Survey of the Caribbean Faunas from the Neogene of the Isthmus of Panama. Bulletins of American Paleontology, Ithaca, NY.

Jordan, D.S. 1888. Description of two new species of fishes from South America. Proceedings of the Academy of Natural Sciences of Philadelphia, 39:387-388.

Jordan, D.S. and Evermann, B.W. 1896. The fishes of North and Middle America: a descriptive catalogue of the species of fish-like vertebrates found in the waters of North America, north of the Isthmus of Panama. Part I. Bulletin of the United States National Museum, 47:1-1240.

Jordan, D.S. and Hannibal, H. 1923. Fossil sharks and rays of the Pacific Slope of North America. Bulletin of the Southern California Academy of Sciences, 22:2763.

Jung, P. 1965. Miocene Mollusca from the Paraguana Peninsula, Venezuela. Bulletins of American Paleontology, 49(223):387-644.

Kent, B.W. 1994. Fossil Sharks of the Chesapeake Bay Region. Egan Ress \& Boyer, Inc., Columbia, Maryland.

Kent, B.W. and Powell, J.G.W. 1999. Reconstructed dentition of the rare lamnoid shark Parotodus benedenii(le Hon) from the Yorktown Formation (Early Pliocene) at Lee Creek Mine, North Carolina. Mosasaur, 6:1-10.

Kiraly, S.J., Moore, J.A., and Jasinski, P.H. 2003. Deepwater and other sharks of the US Atlantic ocean exclusive economic zone. Marine Fisheries Review, 65(4):1-20.

Klimley, P.A. 2013. The Biology of Sharks and Rays. The University of Chicago Press, Chicago.

Kruckow, T. and Thies, D. 1990. Die Neoselachier der Paleokaribik (Pisces: Elasmobranchii). Courier Forschungsinstitut Senckenberg, 119:1-102.

Landau, B.M., Silva, C.A. da., and Heitz, A. in press (Accepted in January 2016). Systematics of the Gastropods of the Lower-Middle Miocene Cantaure Formation, Paraguaná Peninsula, Venezuela. Bulletins of American Paleontology.

Laurito, C.A. 1999. Los seláceos fósiles de la localidad de Alto Guayacán (y otros ictiolitos asociados), Mioceno superior-Plioceno inferior de la Formación Uscari, provincia de Limón, Costa Rica. Laurito, C. (ed.), San José.
Laurito, M.C.A., Calvo, C., Valerio, A.L., Calvo, A., and Chacón, R. 2014. Ictiofauna del Mioceno inferior de la localidad de Pacuare de Tres Equis, formación río Banano, provincia de Cartago, Costa Rica, y descripción de un nuevo género y una nueva especie de scaridae. Revista Geológica de América Central, 50:153-192.

Le Hon, H. 1871. Préliminaires d'un mémoire sur les poissons tertiaires de Belgique, Brussels.

Leigh, E.G., O'Dea, A., and Vermeij, G.J. 2014. Historical biogeography of the Isthmus of Panama. Biological Reviews, 89(1):148-172.

Leriche, M. 1938. Contribution à L'étude des Poissons fossils des pays riverains de la Méditerranée américaine, Venezuela, Trinité, Antiles, Mexique. Mémoires de la Sociéte paléontologique du Suisse, 61:1-52.

Linck, H.F. 1790. Versuch einer Eintheilung der Fische nach den Zähnen. Magazin für das Neueste aus der Physik und Naturgeschichte, 6(3):28-38.

Linnaeus, C. 1758. Systema Naturae per regna tria naturae, secundum classes, ordines, genera, species; cum characteribus, differentiis, synonymis, locis. 10th Ed. Larentii Salvii, Stockholm.

Macellari, C.E. 1995. Cenozoic sedimentation and tectonics of the southwestern Caribbean Pull-Apart Basin, Venezuela and Colombia, p. 757-780. In Tankard, A.J., Suárez, R., and Welsink, H.J. (eds.), Petroleum basins of South America. The American Association of Petroleum Geologists, Memoir.

MacPhee, R.D.E., Iturralde-Vinent, M.A., and Gaffney, E.S. 2003. Domo de Zaza, an Early Miocene vertebrate locality in South-Central Cuba, with notes on the tectonic evolution of Puerto Rico and the Mona Passage. American Museum Novitates, 3394:1-42.

Montes, C., Cardona, A., Jaramillo, C., Pardo, A., Silva, J.C., Valencia, V., Ayala, C., Pérez-Angel, L.C., Rodriguez-Parra, L.A., Ramirez, V., and Niño, H. 2015. Middle Miocene closure of the Central American Seaway. Science, 348(6231):226-229.

Müller, A. 1999. Ichthyofaunen aus dem atlantischen Tertiär der USA. Leipziger Geowissenschaften, 910:1-360.

Müller, J. and Henle, J. 1837. Gattungen der Haifische und Rochen nach einer von ihm mit Hrn. Henle unternommenen gemeinschaftlichen Arbeit über die Naturgeschichte der Knorpelfische. Akademie der Wissenschaften zu Berlin, 1837(2):111-118.

Müller, J. and Henle, J. 1839-1841. Systematische Beschreibung der Plagiostomen, Berlin.

Musick, J.A., Harbin, M.M., and Compagno, L.J.V. 2004. Historical zoogeography of the Selachii, p. 33-78. In Carrier, J.C., Musick, J.A., and Heithaus, M.R. (eds.), Biology of Sharks andTheir Relatives. CRC Press, Washington, D.C.

Nolf, D. and Brzobohatý, R. 1994. Fish otoliths as paleobathymetric indicators. Paleontologia y Evolutió, 2425:255-264

Nolf, D. and Aguilera, O.A. 1998. Fish otoliths from the Cantaure Formation (Early Miocene of Venezuela). 
Bulletin de l'Institut Royal des Science Naturelles de Belgique, Sciences de la Terre, 68:237-262.

O'Dea, A., Jackson, J.B.C., Fortunato, H., Smith, J.T., D'Croz, L., Johnson, K.G., and Todd, J.A. 2007. Environmental change preceded Caribbean extinction by 2 million years. Proceedings of the National Academy of Sciences, 104(13):5501-5506.

Pimiento, C. and Balk, M.A. 2015. Body-size trends of the extinct giant shark Carcharocles megalodon: a deep-time perspective on marine apex predators. Paleobiology, 41(03):479-490.

Pimiento, C. and Clements, C.F. 2014. When did Carcharocles megalodon become extinct? A new analysis of the fossil record. PLOS ONE, 9(10):e111086.

Pimiento, C., Ehret, D.J., MacFadden, B.J., and Hubbell, G. 2010. Ancient nursery area for the extinct giant shark Megalodon from the Miocene of Panama. PLOS ONE, 5(5):e10552.

Pimiento, C., Gonzalez-Barba, G., Hendy, A.J.W., Jaramillo, C., MacFadden, B.J., Montes, C., Suarez, S.C., and Shippritt, M. 2013a. Early Miocene chondrichthyans from the Culebra Formation, Panama: A window into marine vertebrate faunas before closure the Central American Seaway. Journal of South American Earth Sciences, 42:159-170.

Pimiento, C., González-Barba, G., Ehret, D.J., Hendy, A.J., MacFadden, B.J., and Jaramillo, C. 2013b. Sharks and rays (Chondrichthyes, Elasmobranchii) from the late Miocene Gatun Formation of Panama. Journal of Paleontology, 87(5):755-774.

Poey, F. 1876. Enumeratio piscium cubensium (Parte III). Anales de la Sociedad Española de Historia Natural, 5:373-404.

Portell, R.W., Hubbell, G., Donovan, S.K., Green, J.L., Harper, D.A., and Pickerill, R. 2008. Miocene sharks in the Kendeace and Grand Bay formations of Carriacou, The Grenadines, Lesser Antilles. Caribbean Journal of Science, 44(3):279-286.

Probst, J. 1879. Beiträge zur Kenntniss der fossilen Fische aus der Molasse von Baltringen. Hayfische. Jahreshefte des Vereins für vaterländische Naturkunde in Württemberg, 35:127-191.

Purdy, R., Clellan, J.H.M., Schneider, V.P., Applegate, S.P., Meyer, R., and Slaughter, R. 2001. The Neogene sharks, rays and bony fishes from Lee Creek Mine, Aurora, North Carolina. Smithsonian Contributions to Paleobiology, 90:71-202.

Rafinesque, C.S. 1809-1810. Caratteri di alcuni nuovi generi e nuove specie di animali e piante della Sicilia con varie osservazioni sopra i medesimi. Per le stampe di Sanfilippo, Palermo.

Reinecke, T., Louwye, S., Havekost, U., and Moths, H. 2011. The elasmobranch fauna of the late Burdigalian, Miocene, at Werder-Uesen, Lower Saxony, Germany, and its relationships with Early Miocene faunas in the North Atlantic, Central Paratethys and Mediterranean. Palaeontos, 20:1-170.
Reis, M.A.F. 2005. Chondrichthyan fauna from the Pirabas Formation, Miocene of northern Brazil, with comments on paleobiogeography. Anuário do Instituto de geociências, 28(2):31-58.

Rey, O.T. 1996. Estratigrafía de la Península de Paraguaná, Venezuela. Revista de la Facultad de Ingeniería, Universidad Central de Venezuela, 11(1):3545.

Rincón, A.D., Solórzano, A., Benammi, M., Vignaud, P., and McDonald, H.G. 2014. Chronology and geology of an Early Miocene mammalian assemblage in North of South America, from Cerro La Cruz (Castillo Formation), Lara State, Venezuela: implications in the 'changing course of Orinoco River' hypothesis. Andean Geology, 41(3):507-528.

Rüppell, W.P.E.S.E. 1835-1838. Fische des Rothen Meeres, Frankfurt am Main.

Sánchez-Villagra, M.R., Burnham, R.J., Campbell, D.C., Feldmann, R.M., Gaffney, E.S., Kay, R.F., Lozsán, R., Purdy, R., and Thewissen, J.G.M. 2000. A new near-shore marine fauna and flora from the early Neogene of Northwestern Venezuela. Journal of Paleontology, 74(5):957-968.

Santos, R.S. and Travassos, H. 1960. Contribuicão à Paleontologia do estado do Pará. Peixes fósseis da Formacão Pirabas. Monografia, 16. Minísterio da Agricultura, Departamento Nacional da Produção Mineral, Divisao de Geologia e Mineralogia Rio de Janeiro.

Santos, R.S. and Salgado, M.S. 1971. Contribuição à paleontologia do estado do Pará. Novos restos de peixes da Formação Pirabas. Boletim do Museu Paraense Emílio Goeldi, 16:1-13.

Snodgrass, R.E. and Heller, E. 1905. Papers from the Hopkins-Stanford Galapagos Expedition, 1898-1899. XVII. Shore Fishes of the Revillagigedo, Clipperton, Cocos and Galapagos Islands. Proceedings of the Washington Academy of Sciences, 6:333-427.

Suárez, M.E., Encinas, A., and Ward, D. 2006. An Early Miocene elasmobranch fauna from the Navidad Formation, Central Chile, South America. Cainozoic Research, 4(1-2):3-18.

Visaggi, C.C. and Godfrey, S.J. 2010. Variation in composition and abundance of Miocene shark teeth from Calvert Cliffs, Maryland. Journal of Vertebrate Paleontology, 30(1):26-35.

Voigt, M. and Weber, D. 2011. Field Guide for Sharks of the Genus Carcharhinus. Verlag Dr. Friedrich Pfeil, München.

Whitley, G.P. 1929. Additions to the check-list of the fishes of New South Wales. No. 2. Australian Zoologist, 5(4):353-357.

Whitley, G.P. 1940. The Fishes of Australia, Pt. I: The Sharks, Rays, Devilfish, and Other Primitive Fishes of Australia and New Zealand. Royal Zoological Society of New South Wales, Sydney.

Woodward, A.S. 1889. Catalogue of the Fossil Fishes in the British Museum. Part. I. British Museum (Natural History), London. 


\section{APPENDIX 1.}

Elasmobranchii of the Cantaure Formation and their record per localities, jaw position and tooth measurements. Abbreviations: number of specimens $\left(\mathrm{N}^{\circ}\right)$, total number of specimens $\left(\mathrm{N}^{\circ} \mathrm{T}\right)$ and indeterminate (indet.).

\begin{tabular}{|c|c|c|c|c|c|c|c|c|c|c|c|c|c|c|c|}
\hline \multirow[b]{2}{*}{ Taxon } & \multicolumn{9}{|c|}{ Localities } & \multicolumn{3}{|c|}{ Jaw position } & \multicolumn{3}{|c|}{ Teeth measurements $(\mathrm{mm})$} \\
\hline & 1 & $\mathrm{~N}^{\circ}$ & 2 & $\mathrm{~N}^{\circ}$ & 3 & $\mathrm{~N}^{\circ}$ & 4 & $\mathrm{~N}^{\circ}$ & $\mathbf{N}^{\circ} \mathbf{T}$ & Upper & Lower & indet. & Height & Width & Length \\
\hline Heterodontus sp. & 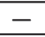 & $\begin{array}{lll}- & & \\
\end{array}$ & $\mathrm{X}$ & 1 & - & - & 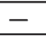 & $\begin{array}{lll}- & & \\
\end{array}$ & 1 & $\begin{array}{lll}- & \\
\end{array}$ & - & 1 & $?$ & $?$ & $?$ \\
\hline Nebrius sp. & $\mathrm{X}$ & 3 & $\mathrm{X}$ & 1 & - & - & - & - & 4 & - & - & 4 & 2 to 11 & 3 to 7 & - \\
\hline †aratodus benedenii & - & - & $\mathrm{X}$ & 1 & - & - & - & - & 1 & $1 ?$ & - & - & 32 & ? & - \\
\hline †Carcharocles megalodon & $\mathrm{X}$ & 1 & $\mathrm{X}$ & 18 & $\mathrm{X}$ & 80 & $\mathrm{X}$ & 7 & 106 & 50 & 31 & 25 & 23 to 127 & 23 to $\sim 66$ & - \\
\hline Alopias cf. Alopias vulpinus & $\mathrm{X}$ & 1 & $\mathrm{X}$ & 1 & $\mathrm{X}$ & 1 & - & 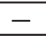 & 3 & 2 & - & 1 & 9 to 11 & 10 to 11 & - \\
\hline Galeorhinus cf. G. galeus & $\mathrm{X}$ & 1 & - & - & - & - & - & $\begin{array}{llll}- & & & \\
\end{array}$ & 1 & 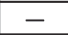 & - & 1 & 2.5 & 5 & - \\
\hline Mustelus sp. & - & - & $\mathrm{X}$ & 3 & - & - & - & - & 3 & - & - & 3 & $<3$ & $<3$ & $<3$ \\
\hline$\dagger$ Hemipristis serra & $\mathrm{X}$ & 2 & $\mathrm{X}$ & 182 & $\mathrm{X}$ & 195 & $\mathrm{X}$ & 46 & 425 & 230 & 70 & 125 & 5 to 32 & 4.5 to 35 & - \\
\hline †Galeocerdo aduncus & $\mathrm{X}$ & 1 & $\mathrm{X}$ & 13 & - & - & - & - & 14 & - & - & 14 & 11 to 18 & 16 to 24 & - \\
\hline †Galeocerdo mayumbensis & $\begin{array}{llll}- & & & \\
\end{array}$ & 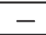 & $\mathrm{X}$ & 8 & $\mathrm{X}$ & 1 & - & $\begin{array}{lll}- & & \\
\end{array}$ & 9 & 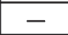 & $\begin{array}{c}- \\
\end{array}$ & 9 & 12 to 22 & 20 to 25.5 & - \\
\hline Rhizoprionodon sp. & $\mathrm{X}$ & 3 & $\mathrm{X}$ & 14 & $\begin{array}{lll}- & & \\
\end{array}$ & - & $\begin{array}{lll}- & & \\
\end{array}$ & $\begin{array}{llll}- & & & \\
\end{array}$ & 17 & 4 & 6 & 7 & 2 to 3.8 & 2.2 to 4 & $\begin{array}{lll}- & & \\
\end{array}$ \\
\hline †Carcharhinus ackermannii & $\mathrm{X}$ & 5 & - & - & - & - & - & - & 5 & 3 & 2 & - & 11 to 18.2 & 12.7 to 20 & - \\
\hline Carcharhinus brachyurus & - & - & $\mathrm{X}$ & 32 & - & - & - & - & 32 & 29 & 3 & - & 8 to 14 & \begin{tabular}{|l|}
8 to 16.1 \\
\end{tabular} & - \\
\hline Carcharhinus falciformis & - & - & $\mathrm{X}$ & 85 & - & - & $\mathrm{X}$ & 17 & 102 & 96 & 6 & - & 3 to 17 & 3 to 15.2 & - \\
\hline Carcharhinus cf. C. galapagensis & 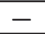 & 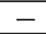 & - & - & $\mathrm{X}$ & 17 & - & $\begin{array}{lll}- & & \\
\end{array}$ & 17 & 17 & - & - & 12 to 17.5 & 13 to 16 & - \\
\hline$\uparrow$ Carcharhinus gibbesii & - & - & $\mathrm{X}$ & 2 & - & - & - & - & 2 & 2 & - & - & 9 to 9.9 & 7.8 to 8 & - \\
\hline Carcharhinus of. C. limbatus & $\mathrm{X}$ & 2 & - & - & - & - & - & - & 2 & 2 & - & - & 5 to 9 & 6.5 to 11 & - \\
\hline Carcharhinus cf. C. macloti & - & - & $\mathrm{X}$ & 2 & - & - & - & - & 2 & 2 & - & - & 3.4 to 6.3 & 4 to 6.7 & - \\
\hline Carcharhinus perezi & $\mathrm{X}$ & 11 & $\mathrm{X}$ & 3 & $\mathrm{X}$ & 1 & - & - & 15 & 15 & - & - & 4 to 8 & 5 to 13 & - \\
\hline Carcharhinus sp. 1 & $\mathrm{X}$ & 8 & - & - & - & - & - & 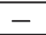 & 8 & 8 & $\begin{array}{ll}- \\
\end{array}$ & $\begin{array}{ll}- \\
\end{array}$ & 2 to 4.5 & 3.2 to 6 & - \\
\hline Carcharhinus spp. & $\mathrm{X}$ & 21 & $\mathrm{X}$ & 50 & $\mathrm{X}$ & 17 & $\mathrm{X}$ & 10 & 98 & 40 & 52 & 6 & 5 to 15 & 4 to 14 & - \\
\hline †Isogomphodon acuarius & $\mathrm{X}$ & 8 & $\mathrm{X}$ & 26 & - & - & - & - & 34 & 18 & 16 & - & 3 to 10.1 & 3.1 to 9.5 & - \\
\hline$\uparrow$ Negaprion eurybathrodon & $\mathrm{X}$ & 13 & $\mathrm{X}$ & 101 & $\mathrm{X}$ & 437 & $\mathrm{X}$ & 35 & 586 & 280 & 306 & - & 6 to 19 & 6 to 22 & - \\
\hline$\uparrow$ Physogaleus contortus & $\begin{array}{llll}- & & & \\
\end{array}$ & 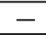 & $\mathrm{X}$ & 30 & $\mathrm{X}$ & 3 & $\mathrm{X}$ & 1 & 34 & - & 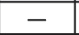 & 34 & 10 to 19 & 19 to 19 & - \\
\hline Carcharhinidae indet. & $\mathrm{X}$ & 2 & $\mathrm{X}$ & 8 & - & - & - & - & 10 & 2 & 8 & - & 3 to 6.2 & 4.5 to 8 & - \\
\hline$\dagger$ †phyrna arambourgi & $\mathrm{X}$ & 14 & $\mathrm{X}$ & 13 & - & - & - & - & 27 & 14 & 12 & 1 & 3 to 7 & 4 to 7.2 & - \\
\hline Sphyrna cf. $\uparrow$ S. laevissima & $\mathrm{X}$ & 2 & $\mathrm{X}$ & 1 & $\mathrm{X}$ & 5 & - & - & 8 & - & 3 & $J$ & 3.5 to 11.9 & 5.5 to 14.9 & - \\
\hline Rhynchobatus sp. & $\mathrm{X}$ & 8 & $\mathrm{X}$ & 7 & - & - & - & $\begin{array}{lll}- & & \\
\end{array}$ & 15 & - & - & 15 & $<4$ & $<4$ & $<4$ \\
\hline Pristis sp. & $\mathrm{X}$ & 5 & $\mathrm{X}$ & 13 & $\mathrm{X}$ & 1 & $\begin{array}{ll}- \\
\end{array}$ & $\begin{array}{llll}- & & & \\
\end{array}$ & 19 & - & - & 19 & $<3$ & $<3$ & $<3$ \\
\hline Dasyatis sp. & $\mathrm{X}$ & 21 & $\mathrm{X}$ & 12 & - & - & - & - & 33 & - & - & 33 & $<3$ & $<3$ & $<3$ \\
\hline cf. Pteroplatytrygon sp. & $\mathrm{X}$ & 5 & - & - & - & - & - & - & 5 & - & - & 5 & $<3$ & $<3$ & $<3$ \\
\hline cf. Taeniurops sp. & $\mathrm{X}$ & 1 & - & - & - & - & - & - & 1 & - & - & 1 & $<3$ & $<3$ & $<3$ \\
\hline Dasyatidae indet. & $\mathrm{X}$ & 2 & $\begin{array}{ll}- \\
\end{array}$ & 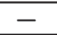 & - & - & $\begin{array}{llll}- & & & \\
\end{array}$ & $\begin{array}{llll}- & & & \\
\end{array}$ & 2 & - & - & 2 & $<3$ & $<3$ & $<3$ \\
\hline Aetobatus sp. & $X$ & 6 & $\mathrm{X}$ & 9 & $X$ & 4 & - & - & 19 & - & - & 19 & 4.1 to 6 & $?$ & $\sim 4.5$ to 10 \\
\hline Aetomylaeus sp. & $\mathrm{X}$ & 2 & $\mathrm{X}$ & 1 & - & - & - & - & 3 & - & - & 3 & $?$ & ? & $?$ \\
\hline Rhinoptera sp. & $\mathrm{X}$ & 15 & $\mathrm{X}$ & 129 & $\mathrm{X}$ & 1 & - & - & 145 & - & - & 145 & 2 to 6 & 5 to 29 & 3 to 8 \\
\hline$\uparrow$ Mobula fragilis & $\mathrm{X}$ & 4 & $\begin{array}{lll}- & \\
\end{array}$ & - & - & 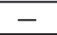 & - & $\begin{array}{llll}- & & & \\
\end{array}$ & 4 & - & - & 4 & 2.5 to 3 & 3.5 to $>6$ & 1 to 1.6 \\
\hline Mobula cf. $\uparrow$ M. loupianensis & $\mathrm{X}$ & 3 & - & - & - & - & - & - & 3 & - & - & 3 & $<2$ & $<2$ & $<2$ \\
\hline Mobula sp. & - & - & $\mathrm{X}$ & 3 & - & - & - & - & 3 & - & - & 3 & $<2$ & $<2$ & $<2$ \\
\hline$\uparrow$ Plinthicus stenodon & - & - & - & - & $\mathrm{X}$ & 1 & - & - & 1 & - & - & 1 & 8 & 15.5 & 4 \\
\hline Myliobatiformes indet. & - & - & $\mathrm{X}$ & 11 & - & - & - & - & 11 & - & - & - & $?$ & $?$ & $?$ \\
\hline Chondrichthyes indet. & $\begin{array}{lll}- & & \\
\end{array}$ & $\begin{array}{lll}- & & \\
\end{array}$ & $\mathrm{X}$ & 6 & $\begin{array}{ll}- \\
-\end{array}$ & $\begin{array}{lll}- & & \\
\end{array}$ & - & $\begin{array}{ll}- \\
-\end{array}$ & 6 & $\begin{array}{ll}- \\
\end{array}$ & $\begin{array}{lll}- & & \\
\end{array}$ & - & $?$ & $?$ & $?$ \\
\hline Total: & & 17 & & 786 & & 764 & & 116 & 1836 & & & & & & \\
\hline
\end{tabular}




\section{APPENDIX 2.}

Referred fossil specimens and collection numbers.

\section{Referred fossil specimens}

- Nebrius sp. [1 tooth (AMU-CURS-982), 1 tooth (AMU-CURS-986)].

- †Paratodus benedenii [1 tooth (AMU-CURS-645)].

$-\uparrow$ Carcharocles megalodon [4 teeth (AMU-CURS-512), 3 teeth (AMU-CURS-513), 2 teeth (AMU-CURS-514), 2 teeth (AMU-CURS-515), 3 teeth (AMU-CURS-516), 4 teeth (AMU-CURS-517), 3 teeth (AMU-CURS-518), 1 tooth (AMU-CURS-519), 4 teeth (AMU-CURS-650), 1 tooth (AMU-CURS-996), 1 tooth (AMU-CURS-997), 1 tooth (AMU-CURS-998), 7 teeth (AMU-CURS-1034), 1 tooth (UNEFM-PF-321), 1 tooth (UNEFM-PF-322), 13 teeth (UNEFM-PF-s/n), 17 teeth (UNEFM-PF-s/n), 21 teeth (UNEFM-PF-s/n), 17 teeth (MCNC-s/n)].

-Alopias cf. A. vulpinus [1 tooth (AMU-CURS-983), 1 tooth (AMU-CURS-984), 1 tooth (AMU-CURS-985)].

-Galeorhinus cf. G. galeus [1 tooth (AMU-CURS-974)].

-Mustelus sp. [3 teeth (AMU-CURS-975)].

$-\uparrow$ Hemipristis serra [66 teeth (AMU-CURS-502), 1 tooth (AMU-CURS-506), 6 teeth (AMU-CURS-520), 24 teeth (AMU-CURS-644), 3 teeth (AMU-CURS-712), 1 tooth (AMU-CURS-731), 1 tooth (AMU-CURS-973), 1 tooth (AMU-CURS-993), 1 tooth (AMU-CURS-994), 1 tooth (AMU-CURS-1014), 461 tooth (AMU-CURS-1031), 156 (UNEFM-PF-s/n), 118 teeth (UNEFM-PF-s/n).

$-\uparrow$ Galeocerdo aduncus [13 teeth (AMU-CURS-647), 1 tooth (AMU-CURS-730)].

-†Galeocerdo mayumbensis [8 teeth (AMU-CURS-646), 1 tooth (AMU-CURS-995)].

-Rhizoprionodon sp. [14 teeth (AMU-CURS-959), 3 teeth (AMU-CURS-960)].

$-\uparrow$ Carcharhinus ackermannii [3 teeth (AMU-CURS-713), 2 teeth (AMU-CURS-714)].

-Carcharhinus brachyurus [28 teeth (AMU-CURS-668), 4 teeth (AMU-CURS-990)].

-Carcharhinus falciformis [72 teeth (AMU-CURS-669), 6 teeth (AMU-CURS-991), 11 teeth (AMU-CURS-953), 17 teeth (AMU-CURS-1035)].

-Carcharhinus cf. C. galapagensis [17 teeth (AMU-CURS-973)].

$-\uparrow$ Carcharhinus gibbesii [2 teeth (AMU-CURS-958)].

-Carcharhinus cf. C. limbatus [2 teeth (AMU-CURS-944)].

-Carcharhinus cf. C. macloti [2 teeth (AMU-CURS-957)].

-Carcharhinus perezi [1 tooth (AMU-CURS-954), 3 teeth (AMU-CURS-955), 11 teeth (AMU-CURS-956)].

-Carcharhinus sp. 1 [8 teeth (AMU-CURS-943)].

-Carcharhinus spp. [22 teeth (AMU-CURS-651), 26 teeth (AMU-CURS-652), 14 teeth (AMU-CURS-940), 7 teeth (AMU-CURS-941), 10 teeth (AMU-CURS-942), 7 teeth (AMU-CURS-972), 1 tooth (AMU-CURS-1015), 1 tooth (AMU-CURS-1017), 10 teeth (AMU-CURS-1085)].

- $\uparrow$ Isogomphodon acuarius [8 teeth (AMU-CURS-950), 25 teeth (AMU-CURS-951), 1 tooth (AMU-CURS-952)].

$-\uparrow$ Negaprion eurybathrodon [165 teeth (AMU-CURS-503), 65 teeth (AMU-CURS-504), 56 teeth (AMU-CURS-505), 1 tooth (AMU-CURS-509), 47 teeth (AMU-CURS-649), 13 teeth (AMU-CURS-987), 1 tooth (AMU-CURS-998), 52 teeth (AMU-CURS-989), 1 tooth (AMU-CURS-1013), 35 (AMU-CURS-1032), 150 teeth (UNEFM-PF-s/n)].

$-\uparrow$ Physogaleus contortus [29 teeth (AMU-CURS-648), 2 teeth (AMU-CURS-992), 1 tooth (AMU-CURS-1033), 1 tooth (AMU-CURS-719), 1 tooth (AMU-CURS-720)]. 


\section{APPENDIX 2 (CONTINUED).}

-Carcharhinidae indet. [2 teeth (AMU-CURS-938), 8 teeth (AMU-CURS-939)].

- $†$ Sphyrna arambourgi [14 teeth (AMU-CURS-961), 13 teeth (AMU-CURS-962)].

-Sphyrna cf. $\dagger$ S. laevissima [1 tooth (AMU-CURS-963), 5 teeth (AMU-CURS-964), 1 tooth (AMU-CURS-965)].

-Rhynchobatus sp. [4 teeth (AMU-CURS-653), 2 teeth (AMU-CURS-654), 3 teeth (AMU-CURS-968), 4 teeth (AMU-CURS-969), 1 tooth (AMU-CURS-970), 1 tooth (AMU-CURS-971)].

-Pristis sp. $[7$ rostral denticles and 1 rostrum fragment (AMU-CURS-242), 1 rostral denticle (AMU-CURS-717), 3 teeth (AMU-CURS-655), 1 tooth (AMU-CURS-1019), 1 tooth (AMU-CURS-966), 5 teeth (AMU-CURS-717)].

-Dasyatis sp. [1 tooth (AMU-CURS-657), 1 tooth (AMU-CURS-658), 12 teeth (AMU-CURS-929), 5 teeth (AMUCURS-930), 10 teeth (AMU-CURS-931), 1 tooth (AMU-CURS-932), 1 tooth (AMU-CURS-933), 1 tooth (AMUCURS-934), 1 tooth (AMU-CURS-935)].

- cf. Pteroplatytrygon sp. [5 teeth (AMU-CURS-926)].

-cf. Taeniurops sp. [1 tooth (AMU-CURS-925)].

-Dasyatidae indet. [1 tooth (AMU-CURS-936), 1 tooth (AMU-CURS-937)].

-Aetobatus sp. [1 tooth (AMU-CURS-508), 1 tooth (AMU-CURS-659), 4 teeth (AMU-CURS-663), 4 teeth (AMUCURS-665), 6 teeth (AMU-CURS-716), 2 teeth (AMU-CURS-718), 1 tooth (AMU-CURS-729)].

-Aetomylaeus sp. [1 tooth (AMU-CURS-750), 2 teeth (AMU-CURS-766)].

-Rhinoptera sp. [80 teeth (AMU-CURS-660), 1 tooth (AMU-CURS-664), 4 teeth (AMU-CURS-977), 6 teeth (AMUCURS-978), 28 teeth (AMU-CURS-979), 11 teeth (AMU-CURS-980), 15 teeth (AMU-CURS-981)].

- $\uparrow$ Mobula fragilis [2 teeth (AMU-CURS-947), 1 tooth (AMU-CURS-948), 1 tooth (AMU-CURS-949)].

-Mobula cf. $\uparrow$ M. loupianensis [3 teeth (AMU-CURS-946)].

-Mobula sp. [3 teeth (AMU-CURS-945)].

$-\dagger$ Plinthicus stenodon [1 tooth (AMU-CURS-715)].

-Myliobatiformes indet. [10 caudal spines (AMU-CURS-507), 1 tooth (AMU-CURS-510), 1 tooth (AMU-CURS1018)].

-Chondrichthyes indet. [4 vertebrae (AMU-CURS-511), 2 denticles (AMU-CURS-656)]. 


\section{APPENDIX 3.}

Bathymetric and feeding preferences of the Cantaure Formation elasmobranch taxa, based on the biology of their extant relatives. The gray shadow indicates the feeding preferences. Abbreviations: minimun $(\mathrm{Mn})$, maximun $(\mathrm{Mx})$ and meters $(\mathrm{m})$.

\begin{tabular}{|c|c|c|c|c|c|c|c|c|c|c|c|c|c|c|c|c|}
\hline \multirow{4}{*}{ Cantaure Formation taxa } & \multirow{4}{*}{ Extant species } & \multirow{2}{*}{\multicolumn{8}{|c|}{ Habitat of living representatives }} & \multicolumn{7}{|c|}{ Feeding ecology } \\
\hline & & & & & & & & & & & havior & & & Diet & & \\
\hline & & \multirow{2}{*}{ 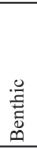 } & \multirow{2}{*}{ 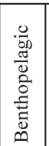 } & \multirow{2}{*}{ 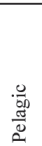 } & \multirow{2}{*}{ 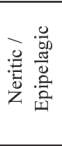 } & \multirow{2}{*}{ 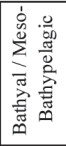 } & \multicolumn{2}{|c|}{$\begin{array}{c}\text { Bathymetry } \\
\text { depth (m) }\end{array}$} & \multirow[t]{2}{*}{ Comments } & \multirow{2}{*}{ 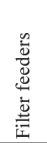 } & \multirow{2}{*}{ 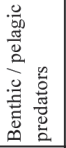 } & \multirow{2}{*}{ 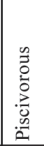 } & \multirow{2}{*}{ 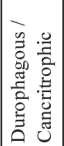 } & \multirow{2}{*}{ 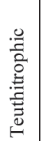 } & \multirow{2}{*}{ 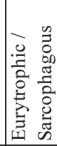 } & \multirow{2}{*}{ 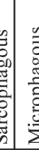 } \\
\hline & & & & & & & $\mathrm{Mn}$ & $\mathrm{Mx}$ & & & & & & & & \\
\hline Heterodontus sp. & Heterodontus spp. & $\mathrm{X}$ & & & $\mathrm{X}$ & $\mathrm{X}$ & 0 & 280 & & & $\mathrm{X}$ & $\mathrm{X}$ & $\mathrm{X}$ & & & \\
\hline Nebrius sp. & Nebrius ferrugineus & $\mathrm{X}$ & & & $\mathrm{X}$ & & 1 & 70 & usually less than $30 \mathrm{~m}$ & & $\mathrm{X}$ & $\mathrm{X}$ & $\mathrm{X}$ & $\mathrm{x}$ & & \\
\hline$\dagger$ Paratodus benedenii & - & & & $\mathrm{X}$ & $\mathrm{X}$ & $?$ & $?$ & $?$ & & & $\mathrm{X}$ & $\mathrm{X}$ & & & $?$ & \\
\hline$\dagger$ †archarocles megalodon & - & & $?$ & $\mathrm{X}$ & $\mathrm{X}$ & $?$ & 0 & $?$ & & & & $\mathrm{X}$ & & & $\mathrm{X}$ & \\
\hline Alopias cf. A. vulpinus & Alopias vulpinus & & & $\mathrm{X}$ & $\mathrm{X}$ & $\mathrm{X}$ & 0 & 550 & usually less than $200 \mathrm{~m}$ & & & $\mathrm{X}$ & & $\mathrm{X}$ & & \\
\hline Galeorhinus cf. G. galeus & Galeorhinus galeus & & $\mathrm{X}$ & & $\mathrm{X}$ & $\mathrm{X}$ & 0 & 1100 & usually $2-400 \mathrm{~m}$ & & $\mathrm{X}$ & $\mathrm{X}$ & $\mathrm{x}$ & $\mathrm{x}$ & & \\
\hline Mustelus sp. & Mustelus spp. & & $\mathrm{X}$ & & $\mathrm{X}$ & $\mathrm{X}$ & 0 & 900 & & & $\mathrm{X}$ & $\mathrm{X}$ & $\mathrm{X}$ & & & \\
\hline$\dagger$ Hemipristis serra & Hemipristis elongata & & $\mathrm{X}$ & & $\mathrm{X}$ & & 0 & $\sim 130$ & & & $\mathrm{X}$ & $\mathrm{X}$ & & $?$ & $?$ & \\
\hline$\dagger$ Galeocerdo aduncus & Galeocerdo cuvier & & $\mathrm{X}$ & & $\mathrm{X}$ & $?$ & 0 & $\sim 370$ & usually less than $150 \mathrm{~m}$ & & $\mathrm{X}$ & $\mathrm{X}$ & $\mathrm{X}$ & $\mathrm{X}$ & $\mathrm{X}$ & \\
\hline$\dagger$ Galeocerdo mayumbensis & Galeocerdo cuvier & & $\mathrm{X}$ & & $\mathrm{X}$ & ? & & $\sim 370$ & usually less than $150 \mathrm{~m}$ & & $\mathrm{X}$ & $\mathrm{X}$ & $\mathrm{x}$ & $\mathrm{x}$ & $\mathrm{X}$ & \\
\hline Rhizoprionodon sp. & Rhizoprionodon spp. & & $\mathrm{X}$ & & $\mathrm{X}$ & & 0 & 500 & usually less than $100 \mathrm{~m}$ & & $\mathrm{X}$ & $\mathrm{X}$ & $\mathrm{x}$ & $\mathrm{x}$ & & \\
\hline$\dagger$ †archarhinus ackermannii & Carcharhinus spp. & & $?$ & $\mathrm{X}$ & $\mathrm{X}$ & $?$ & 0 & $>100 ?$ & & & $\mathrm{X}$ & $\mathrm{X}$ & & & & \\
\hline Carcharhinus brachyurus & Carcharhinus brachyurus & & $\mathrm{X}$ & & $\mathrm{X}$ & $\mathrm{X}$ & 0 & $\sim 360$ & usually less than $100 \mathrm{~m}$ & & $\mathrm{X}$ & $\mathrm{x}$ & & $\mathrm{x}$ & & \\
\hline Carcharhinus falciformis & Carcharhinus falciformis & & & $\mathrm{X}$ & $\mathrm{X}$ & $\mathrm{X}$ & 0 & 4000 & most in waters $>200 \mathrm{~m}$ & & $\mathrm{X}$ & $\mathrm{X}$ & & $\mathrm{X}$ & & \\
\hline Carcharhinus cf. C. galapagensis & Carcharhinus galapagensis & & $\mathrm{X}$ & & $\mathrm{X}$ & & 0 & 180 & & & $\mathrm{X}$ & $\mathrm{x}$ & & & & \\
\hline †Carcharhinus gibbesii & Carcharhinus spp. & & ? & $\mathrm{X}$ & $\mathrm{X}$ & ? & 0 & $>100$ ? & & & $\mathrm{X}$ & $\mathrm{X}$ & & $\mathrm{X}$ & & \\
\hline Carcharhinus cf. C. limbatus & Carcharhinus limbatus & & $\mathrm{X}$ & & $\mathrm{X}$ & & 0 & 100 & usually less than $30 \mathrm{~m}$ & & $\mathrm{X}$ & $\mathrm{X}$ & & $\mathrm{x}$ & & \\
\hline Carcharhinus cf. C. macloti & Carcharhinus macloti & & & $\mathrm{X}$ & $\mathrm{X}$ & & 0 & 170 & & & $\mathrm{X}$ & $\mathrm{x}$ & & $\mathrm{x}$ & & \\
\hline Carcharhinus perezi & Carcharhinus perezi & & $\mathrm{X}$ & & $\mathrm{X}$ & & 0 & 65 & usually less than $30 \mathrm{~m}$ & & $\mathrm{X}$ & $\mathrm{X}$ & & & & \\
\hline Carcharhinus sp. 1 & Carcharhinus spp. & & $?$ & $?$ & $\mathrm{X}$ & $?$ & 0 & $>100 ?$ & & & & $\mathrm{X}$ & & & & \\
\hline Carcharhinus spp. & Carcharhinus spp. & & $\mathrm{X}$ & $\mathrm{X}$ & $\mathrm{X}$ & $?$ & 0 & $>100$ ? & & & $\mathrm{X}$ & $?$ & ? & ? & & \\
\hline$\uparrow$ Isogomphodon acuarius & Isogomphodon oxyrhynchus & & $\mathrm{X}$ & & $\mathrm{X}$ & & 0 & 40 & & & $\mathrm{X}$ & $\mathrm{x}$ & & & & \\
\hline$\dagger$ Negaprion eurybathrodon & Negaprion brevirostris & & $\mathrm{x}$ & & $\mathrm{x}$ & & 0 & 92 & & & $\mathrm{X}$ & $\mathrm{X}$ & & & & \\
\hline$\uparrow$ Physogaleus contortus & - & & $?$ & $\mathrm{X}$ & $\mathrm{X}$ & $?$ & $?$ & $?$ & & & $\mathrm{X}$ & $\mathrm{X}$ & & & & \\
\hline Carcharhinidae indet. & Carcharhinidae spp. & & $?$ & $?$ & $\mathrm{X}$ & $?$ & 0 & $>100 ?$ & & & $\mathrm{X}$ & $\mathrm{x}$ & & & & \\
\hline$\dagger$ †phyrna arambourgi & Sphyrna spp. & & $\mathrm{X}$ & & $\mathrm{X}$ & $?$ & 0 & $>100 ?$ & & & $\mathrm{X}$ & $\mathrm{X}$ & & & & \\
\hline Sphyrna cf. $† S$. laevissima & Sphyrna zygaena & & $\mathrm{X}$ & & $\mathrm{X}$ & & 0 & $>100 ?$ & usually less than $20 \mathrm{~m}$ & & $\mathrm{X}$ & $\mathrm{x}$ & & & & \\
\hline Rhynchobatus sp. & Rhynchobatus spp. & & $\mathrm{X}$ & & $\mathrm{X}$ & & 0 & $\sim 60$ & & & $\mathrm{X}$ & $\mathrm{X}$ & $\mathrm{X}$ & & & \\
\hline Pristis sp. & Pristis spp. & & $\mathrm{x}$ & & $\mathrm{x}$ & & 0 & $\sim 120$ & most in waters $<20 \mathrm{~m}$ & & $\mathrm{X}$ & $\mathrm{X}$ & $\mathrm{X}$ & & & \\
\hline Dasyatis sp. & Dasyatis spp. & $\mathrm{X}$ & & & $\mathrm{X}$ & $\mathrm{X}$ & 0 & -470 & most in waters $<50 \mathrm{~m}$ & & $\mathrm{X}$ & $\mathrm{X}$ & $\mathrm{X}$ & & & \\
\hline cf. Pteroplatytrygon $s p$. & Pteroplatytrygon violacea & $\mathrm{x}$ & & & $\mathrm{X}$ & $\mathrm{X}$ & 0 & 381 & usually $1-100 \mathrm{~m}$ & & $\mathrm{X}$ & $\mathrm{X}$ & $\mathrm{X}$ & $\mathrm{x}$ & & \\
\hline cf. Taeniurops & Taeniurops spp. & $\mathrm{X}$ & & & $\mathrm{X}$ & $\mathrm{X}$ & 10 & 500 & usually $20-60 \mathrm{~m}$ & & $\mathrm{X}$ & $\mathrm{X}$ & $\mathrm{X}$ & & & \\
\hline Dasyatidae indet. & Dasyatidae spp. & $\mathrm{X}$ & & & $\mathrm{X}$ & $\mathrm{X}$ & 0 & -470 & & & $\mathrm{X}$ & $\mathrm{X}$ & $\mathrm{x}$ & & & \\
\hline Aetobatus sp. & Aetobatus spp. & & $\mathrm{x}$ & & $\mathrm{X}$ & & 0 & $\sim 100$ & usually less than $40 \mathrm{~m}$ & & $\mathrm{X}$ & $\mathrm{X}$ & $\mathrm{x}$ & $\mathrm{x}$ & & \\
\hline Aetomylaeus sp. & Aetomylaeus spp. & & $\mathrm{x}$ & & & & 0 & 110 & & & $\mathrm{X}$ & $\mathrm{X}$ & $\mathrm{x}$ & $\mathrm{x}$ & & \\
\hline Rhinoptera sp. & Rhinoptera spp. & & $\mathrm{X}$ & & $\mathrm{X}$ & & 0 & $<60$ & usually less than $30 \mathrm{~m}$ & & $\mathrm{X}$ & $\mathrm{X}$ & $\mathrm{x}$ & & & \\
\hline$\dagger$ Mobula fragilis & Mobula spp. & & & $\mathrm{X}$ & $\mathrm{X}$ & $?$ & 0 & $>200$ & usually less than $100 \mathrm{~m}$ & $\mathrm{X}$ & & & & & & $\mathrm{X}$ \\
\hline Mobula cf. $†$ M. loupianensis & Mobula spp. & & & $\mathrm{X}$ & $\mathrm{X}$ & $?$ & 0 & $>200$ & usually less than $100 \mathrm{~m}$ & $\mathrm{X}$ & & & & & & $\mathrm{X}$ \\
\hline Mobula sp. & Mobula spp. & & & $\mathrm{X}$ & $\mathrm{X}$ & $?$ & 0 & $>200$ & usually less than $100 \mathrm{~m}$ & $\mathrm{X}$ & & & & & & $\mathrm{X}$ \\
\hline$\uparrow$ Plinthicus stenodon & - & & $\mathrm{X}$ & & $\mathrm{X}$ & $?$ & $?$ & $?$ & & $\mathrm{X}$ & & & & & & $\mathrm{X}$ \\
\hline Myliobatiformes indet. & - & $?$ & $?$ & ? & $?$ & $?$ & $?$ & $?$ & & $?$ & $?$ & & & & & \\
\hline Chondrichthyes indet. & - & $?$ & $?$ & $?$ & $?$ & $?$ & $?$ & $?$ & & & & & & & & \\
\hline
\end{tabular}




\section{APPENDIX 4.}

Relative abundance of elasmobranchs in the Cantaure Formation. 1. Abundance percentage per locality per taxon. 2. Total abundance per locality. Ht: Heterodontiformes; Or: Orectolobiformes; La: Lamniformes; Ca: Carcharhiniformes; Ra: Rajiformes; My: Myliobatiformes; In: Indeterminate; Loc.: locality; †: extint taxon. *: Percentage does not include Carcharhinus spp., Myliobatiformes indet. and Chondrichthyes indet.

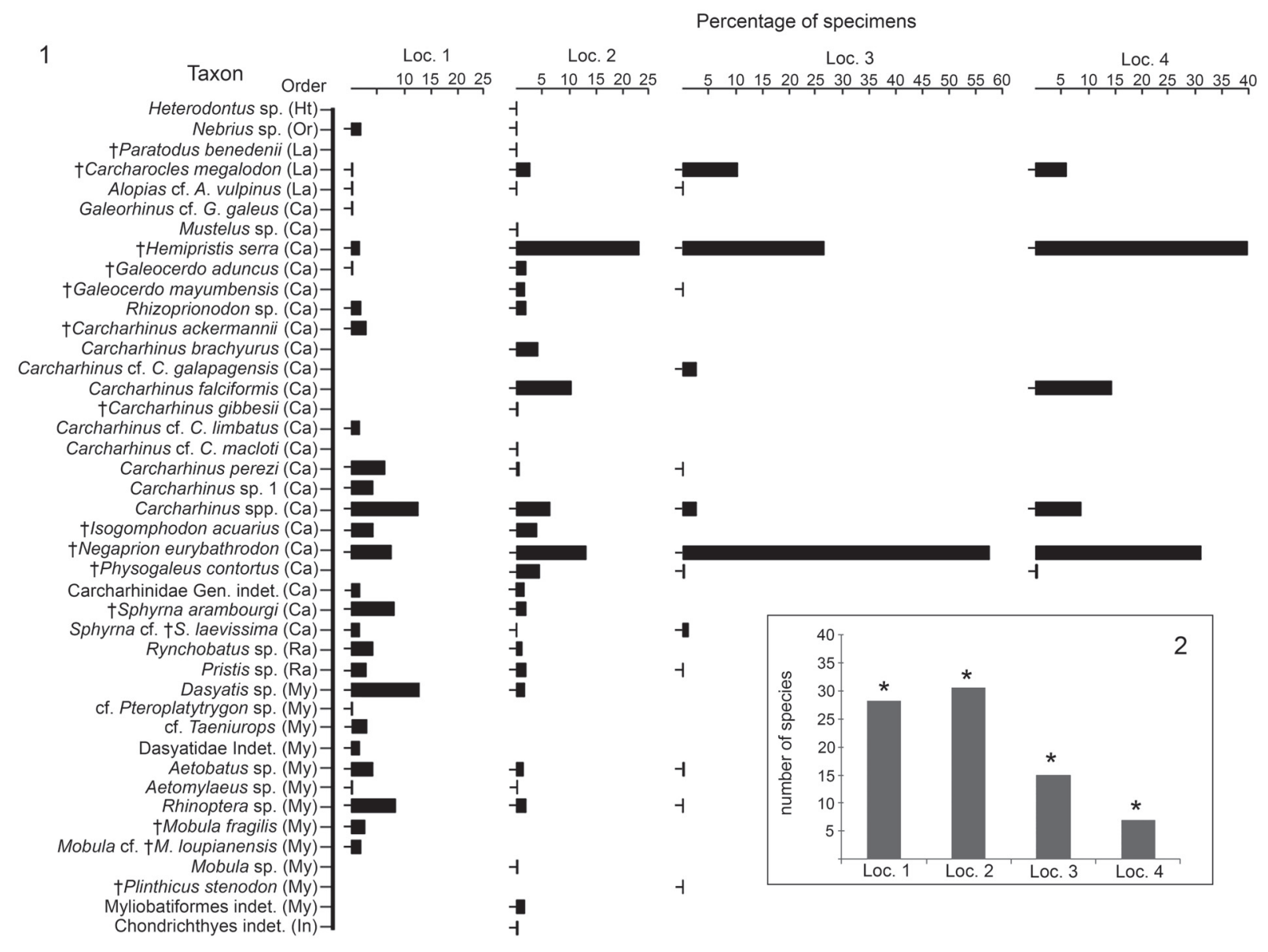

